Biofuel Research Journal 22 (2019) 962-979
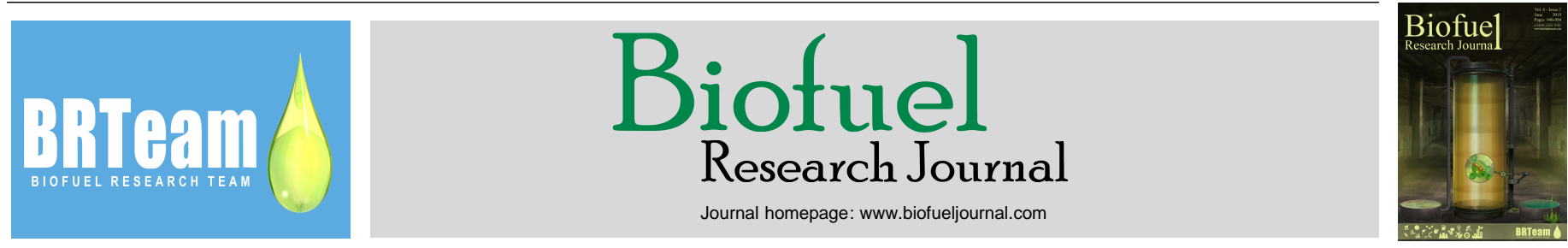

Review Paper

\title{
A review on biomass: importance, chemistry, classification, and conversion
}

\section{Antonio Tursi*}

Department of Chemistry and Chemical Technologies, University of Calabria, Via P. Bucci, Cubo 15D, 87036 Arcavacata di Rende (Cs), Italy.

\section{HIGHLIGHTS}

$>$ Overview of biomass sources and related chemical composition are presented.

$>$ Biomass conversion technologies and final products are reviewed and discussed.

$>$ Economic and environmental analysis of biomassderived energy production was presented.

$>$ Challenges for further expanssion of biomassderived energy production are presented.

\section{GRAPHICAL ABSTRACT}

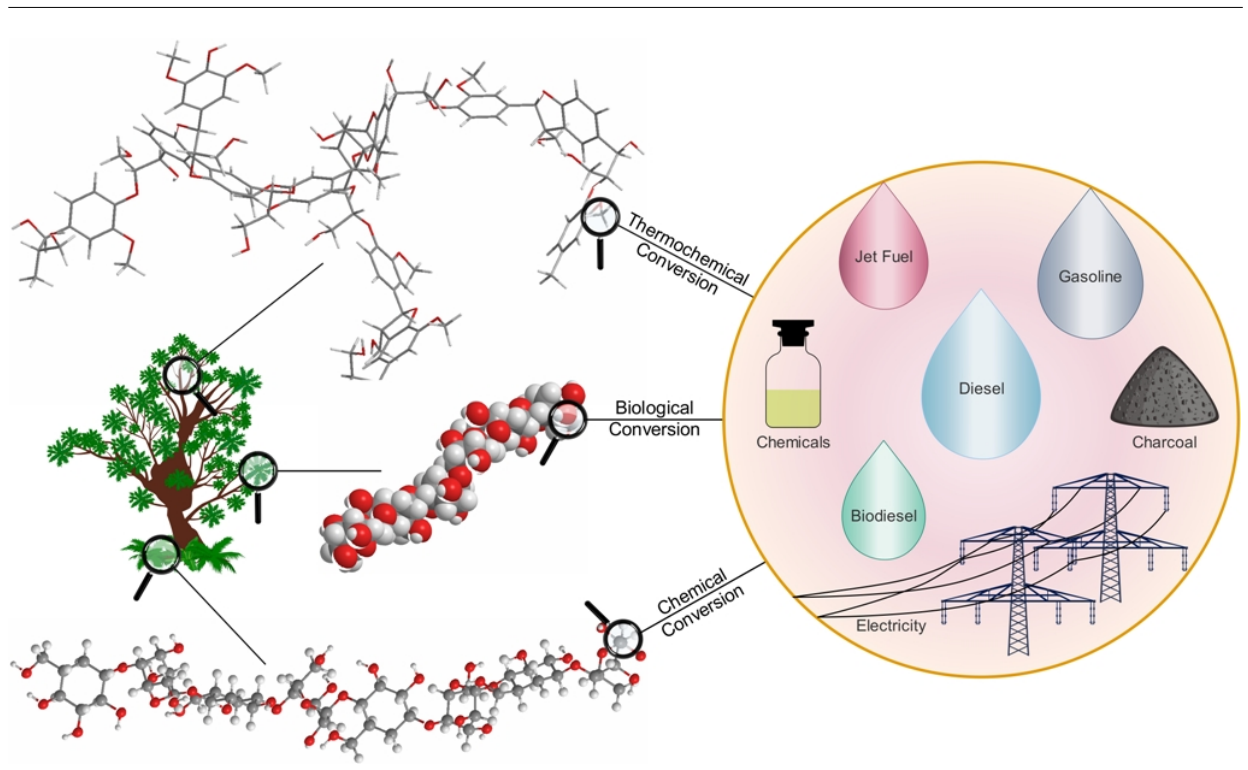

\section{ARTICLE INFO}

\section{Article history:}

Received 17 February 2019

Received in revised form 29 April 2019

Accepted 5 May 2019

Available online 1 June 2019

\section{Keywords:}

Biomass

Lignocelluloses

Pretreatment

Conversion

Biofuels

Sustainability

\section{ABSTRACT}

Biomass is currently the most widespread form of renewable energy and its exploitation is further increasing due to the concerns over the devastative impacts of fossil fuel consumption, i.e., climate change, global warming and their negative impacts on human health. In line with that, the present articles reviews the different sources of biomass available, along with their chemical composition and properties. Subsequently, different conversion technologies (i.e., thermo-chemical, biochemical, and physicochemical conversions) and their corresponding products are reviewed and discussed. In the continuation, the global status of biomass vs. the other renewable energies is scrutinized. Moreover, biomass-derived energy production was analyzed from economic and environmental perspectives. Finally, the challenges faced to further expand the share of biomass-derived energy carriers in the global energy market are presented.

* Corresponding author at: Tel.: +39 3401859667

E-mail address: antonio.tursi@unical.it

Please cite this article as: Tursi A. A review on biomass: importance, chemistry, classification, and conversion. Biofuel Research Journal 22 (2019) $962-979$. DOI: 10.18331/BRJ2019.6.2.3 


\section{Contents}

1. Introduction.

2. Chemical characterization of biomass

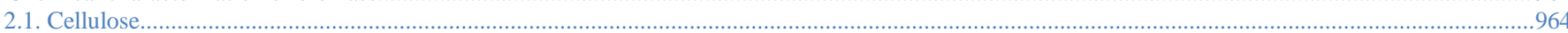

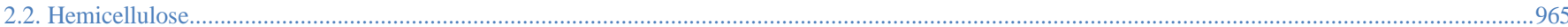

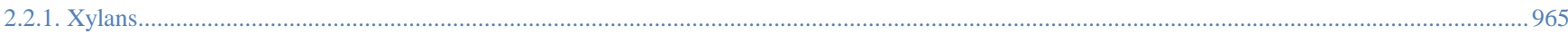

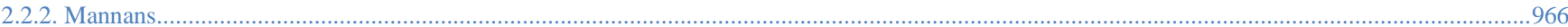

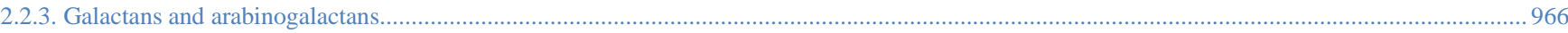

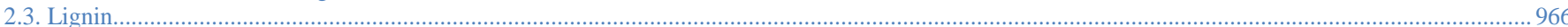

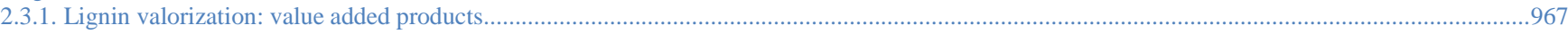

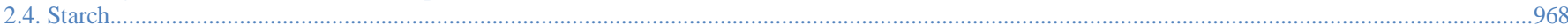

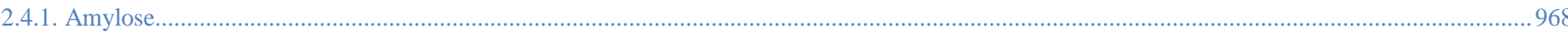

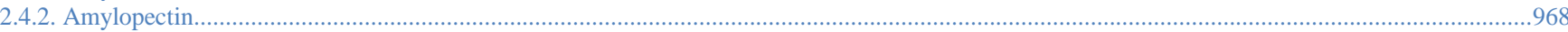

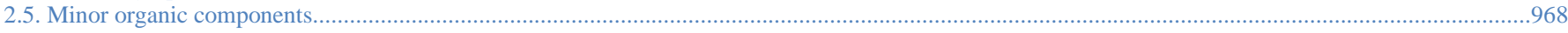

2.6. Inorganic matter

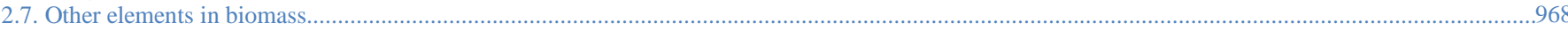

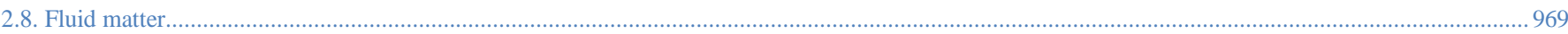

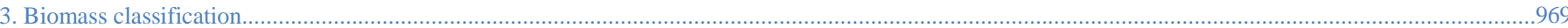

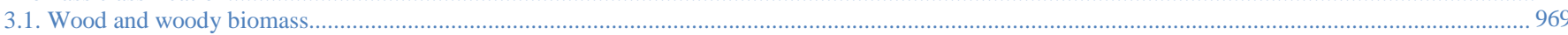

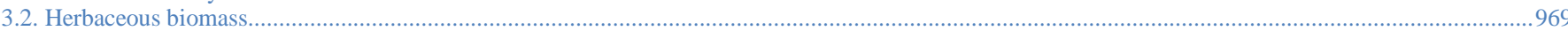

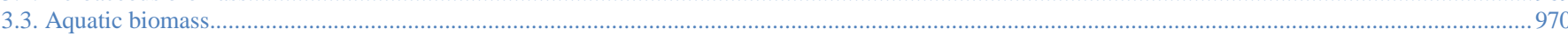

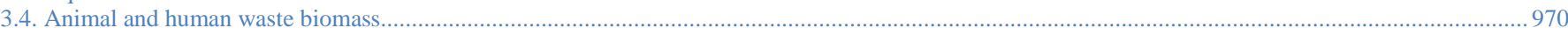

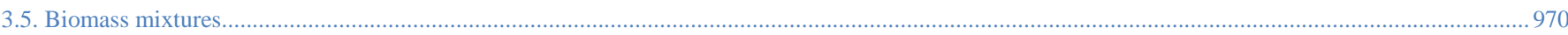

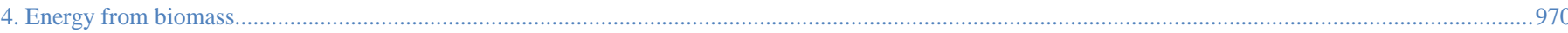

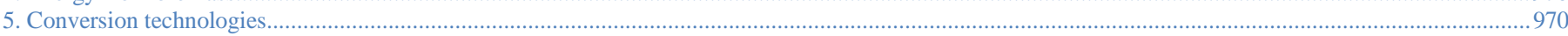

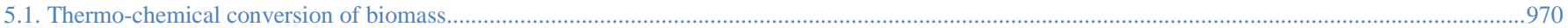

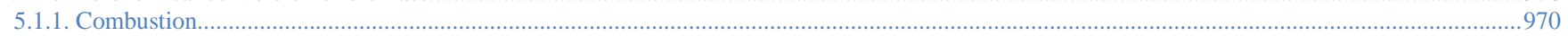

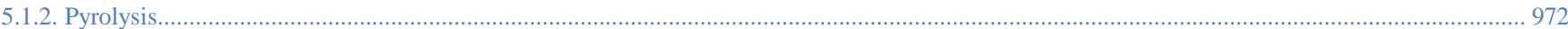

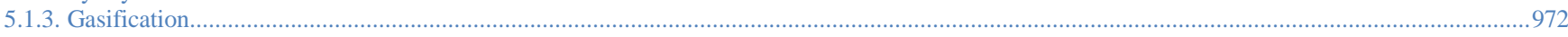

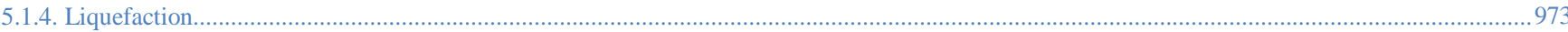

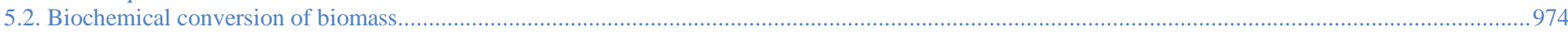

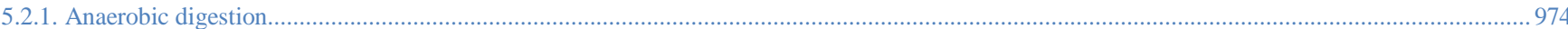

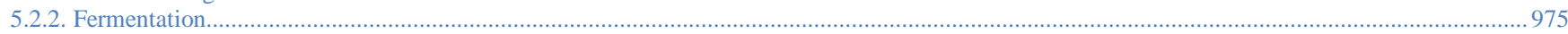

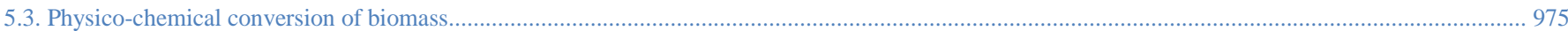

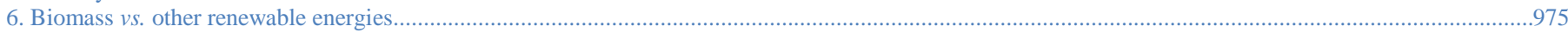

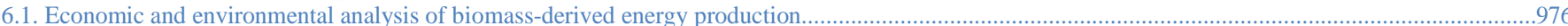

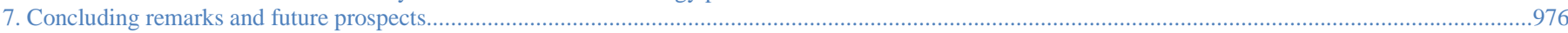

References.

\section{Introduction}

The decades we are living are characterized by growth in wealth, but also by higher levels of pollution and the consequent deterioration of public health, mainly due to the increasing usage of fossil fuels for industrial and postindustrial development. As a result, the global society has been striving to find alternative routes for energy production. In line with that, major institutions of several countries have tried to implement a shared regulatory framework to promote renewable energies, thereby diversifying the sources of supply through replacing conventional energy resources.

Considering various alternative energy sources, biomass has been an indispensable part of energy debates within the policy context, strongly desired by the European Union, which has been able to transform saving and environmental protection provisions into strategic execution plans for development.

In fact, biomass could plays a significant role as source of renewable energy (Lauri et al., 2014), with huge potentials in the production of biofuels for transportation, electricity, and heat (Lebaka, 2013). In industrialized countries, the economic and political importance of bioenergy is recognized, as proved by initiatives like "Biomass Action Plan" and the "Multi-Year Plan", prepared by the European Commission and the US Department of Energy, respectively (Chum et al., 2011). The former document underlines the need of reducing carbon dioxide $\left(\mathrm{CO}_{2}\right)$ emissions, thereby complying with the commitments signed at the Kyoto Protocol and, especially with respect to the countries not involved in the ratification through increasing their awareness on the issue of global warming; a crucial topic of global importance over the last few years.
The latter document is related to the agricultural and energy policies undertaken by several countries. As part of the agricultural policies, the promotion of bioenergy has increased, leading to a different and more productive use of land and has significantly contributed to the creation of economic opportunities in rural areas, including improvement of farmers' income, containment of the countryside-city migrations, as well as conservation of environment and rural culture.

In addition to these, the problem of climate change has brought countries to higher levels of commitments and new bodies have been created by the scientific community like the International Panel on Climate Change (IPCC) in 1988, in order to limit the production of greenhouse gases (GHGs) released into the atmosphere (Chum et al., 2011; Kaltschmitt, 2013); mainly deriving from the consumption of fossil fuels. This debate has been on going in parallel with the importance of renewable energies, with a closer focus on biomass, as an instrumental element of energy security and sustainable development. With the recent scientific discoveries concerning biomass exploitation, promising techniques have been developed capable of optimized production of electricity, heat, and liquid biofuels from these inexpensive abundant natural materials.

It should be noted that biomass is a completely renewable energy resource, because $\mathrm{CO}_{2}$ released through its combustion and utilization processes does not lead to an increase in atmospheric carbon dioxide as it is of biogenic origin. In better words, plants use $\mathrm{CO}_{2}$, released into the environment as a consequence of the degradation processes of the other plants, for their growth and for their metabolic processes (Tkemaladze and Makhashvili, 2016). Therefore, the exploitation of biomass only leads to a 


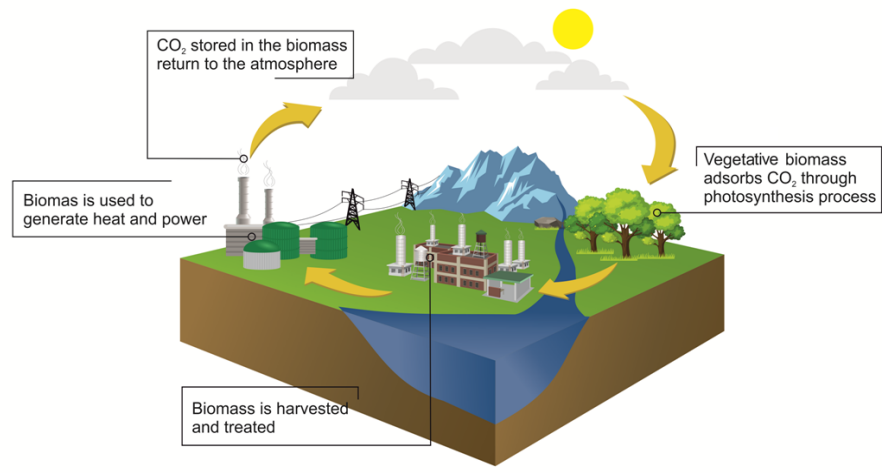

Fig. 1. Carbon cycle throughout the production and utilization of biomass.

faster transfer of $\mathrm{CO}_{2}$ into the atmosphere that will be used again by plants to produce biomass again (Fig. 1) (Kaltschmitt, 2013).

Every organic substance deriving directly or indirectly from the photosynthesis process is considered biomass (Jacobsson and Johnson, 2000). Due to the heterogeneity of the materials, the usage and the origin, the definition of biomass varies. Nevertheless, more generally, biomass is a combination of naturally derived materials, originating from plants such as shrubs, trees, algae, crops as well as all the materials composed of organic matrix except for plastics originating from petrochemical and fossil materials (McKendry, 2002a).

The most important biomass sources (illustrated in Fig. 2) are agricultural and forestry residues (wastes from the wood processing industry such as shavings, sawdust, etc.), animal residues (livestock farms), sewage, algae, and aquatic crops. Municipal solid waste (MSW) and the waste streams originating from anthropogenic activities also fall in the biomass category; only if they are not reusable in subsequent processing (Kaltschmitt, 2013).

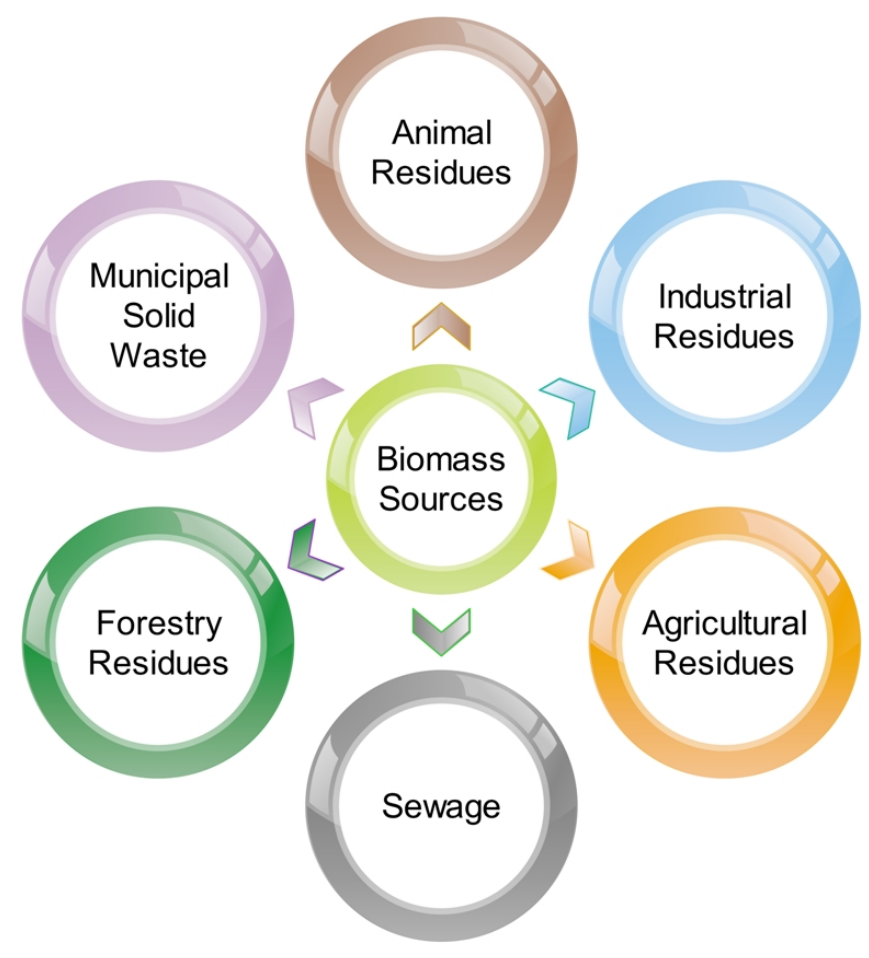

Fig. 2. The most important biomass sources.
Our planet stores a huge amount of biomass available in different areas ranging from forests to oceans. Several reports estimate that the world's total biomass land and aquatic reserves are around 1.8 trillion tons and 4 billion tons, respectively. From an energy point of view, the total biomass in the world has a potential production capacity of $33,000 \mathrm{EJ}$ corresponding to more than 80 times the annual energy consumption in the world (WBA, 2018). However, currently, biomass is partially exploited, accounting for only $14 \%$ of the primary energy in the world, standing at approximately 56 million TJ/yr (1,230 Mtoe/yr). Moreover, the use of this resource does not show a homogenous distribution across the world. More specifically, in some developing countries biomass generates up to $50 \%$ of the total energy needs, through the combustion of wood, shrubs, as well as wastes of plant and animal origins while on the other hand, in the developed countries biomass energy production on average stands at approximately $11 \%$ of the total energy produced (Chum et al., 2011; WBA, 2018). For instance, the United States meets about $3 \%$ of the country`s energy demands by using biomass, corresponding to around 3.2 million TJ/yr (70 Mtoe/yr). The Europe also obtains 3.5\% of its energy from biomass (around $40 \mathrm{Mtoe} / \mathrm{yr}$ ), while some countries like Finland, Sweden, and Austria are well above the average, producing $18 \%, 17 \%$, and $13 \%$ of their total energy from biomass, respectively (Habert et al., 2010).

Overall, considering the huge potentials for the exploitation of biomass as an energy source, some central and northern European countries have set up large plants for heat and power cogeneration using biomass. France, for example, with the largest agricultural lands among the European countries, has implemented a comprehensive tax exemption policy on the production of biodiesel and ethanol, in order to encourage their production. On the other hand, Great Britain has a negligible production of biofuels owing to economic considerations but is focused on the development of huge and effective biogas recovery systems from landfills, both for heat and electricity generation. Other countries like Sweden and Austria traditionally rely on persistent use of firewood for heating and district heating purposes with a tendency towards the coppice plantations (willow, poplar), having higher yields compared with other resources (Habert et al., 2010).

\section{Chemical characterization of biomass}

The composition of biomass is largely diverse. For example, residues of plant origin are mainly composed of cellulose, hemicellulose, and lignin with varying percentages (Fig. 3 and Table 1), while cattle manure is rich in proteins and cereals are mainly composed of starch. Different chemica structures obviously result in different chemical properties (Yokoyama, 2008).

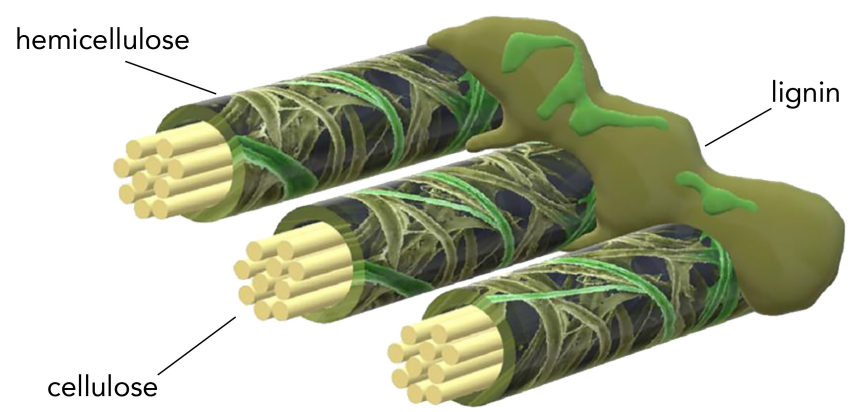

Fig. 3. Structure of lignocellulosic biomass.

\subsection{Cellulose}

Cellulose, a linear polymer, is a complex carbohydrate (or polysaccharide) with a high molecular weight and a maximum of 10,000 monomeric units of D-glucose, linked by $\beta$-1,4-glycosidic bonds. Cellulose 
Table 1.

Structure and chemical composition of cellulose, hemicellulose, and lignin in plant cell walls (Xu et al., 2005; Chen, 2014).

\begin{tabular}{|c|c|c|c|c|}
\hline $\begin{array}{l}\text { Compositional } \\
\text { element }\end{array}$ & Subunits & Subunits bonds & Composition & Polymer \\
\hline Cellulose & D-Pyranglucose units & $\beta-1,4$-Glycosidic bonds & $\beta$-Glucan & Several hundred to tens of thousands \\
\hline Hemicellulose & $\begin{array}{l}\text { D-Xylose, mannose, } \\
\text { L-arabinose, galactose, } \\
\text { glucuronic acid }\end{array}$ & $\begin{array}{l}\beta-1,4-\text { Glycosidic bonds in main chains; } \\
\beta-1.2-, \beta-1.3-, \beta-1.6 \text {-glycosidic bonds in side } \\
\text { chains }\end{array}$ & $\begin{array}{l}\text { Polyxylose } \\
\text { Galactoglucomannan (Gal-Glu-Man) } \\
\text { Glucomannan (Glu-Man) }\end{array}$ & Less than 200 \\
\hline Lignin & $\begin{array}{l}\text { Guaiacylpropane }(\mathrm{G}), \\
\text { syringylpropane }(\mathrm{S}), \\
\text { p-hydroxyphenylpropane }(\mathrm{H})\end{array}$ & $\begin{array}{l}\text { Various ether bonds (mainly } \beta-\mathrm{O}-4 \text { ); carbon- } \\
\text { carbon bond }\end{array}$ & $\begin{array}{l}\text { G lignin, } \\
\text { GS lignin, } \\
\text { GSH lignin }\end{array}$ & 4,000 \\
\hline
\end{tabular}

molecular formula is $\left(\mathrm{C}_{6} \mathrm{H}_{12} \mathrm{O}_{6}\right)_{\mathrm{n}}$ ( $\mathrm{n}$ indicates the degree of polymerization) and its structural base is cellobiose (i.e., 4-o- $\beta-D-$ glucopyranosyl-Dglucopyranose) (Fig. 4).

Cellulose is the most abundant organic compound that can be found in nature (e.g., $90 \%$ and $50 \%$ of cotton and wood structure are contributed by cellulose, respectively) possessing a structural function in plant cell walls (Bonechi et al., 2017).

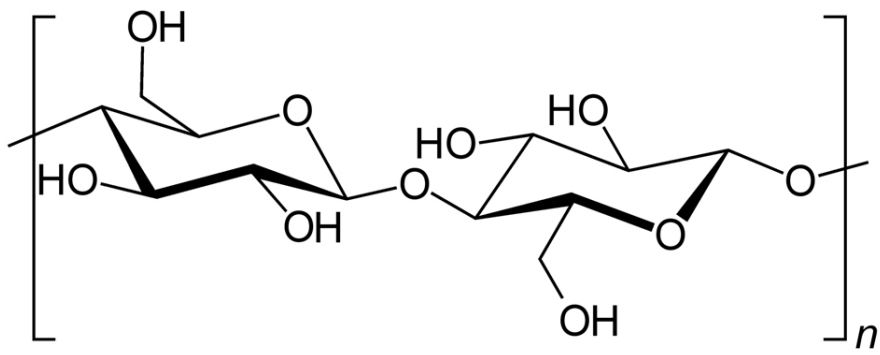

Fig. 4. The structural formula of cellulose

The reactivity and morphology of cellulose chains are substantially influenced by the intermolecular hydrogen bond between the hydroxyl group on C-3 carbon and the oxygen of the nearby glycosidic ring. The formation of these bonds makes the molecules more stable and rigid. In some cases, the presence of many intermolecular bonds can generate an orderly crystalline region due to the considerable proximity between the different monomers (Fig. 5) (Chen, 2014)

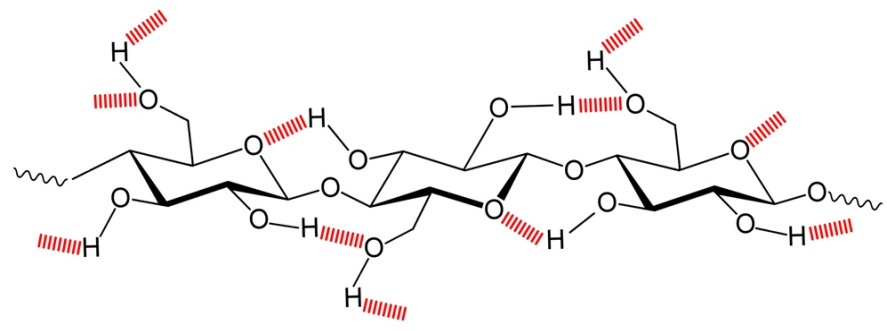

Fig. 5. Inter and intra-molecular hydrogen bonding in cellulose.

Alternation of the crystalline and amorphous regions of cellulose could affect the accessibility of its functional groups, which are involved in reactions. In fact, the reactivity of cellulose depends on the reactive capacity of its primary and the secondary hydroxyl groups, emerging from the glycosidic rings. In particular, the primary hydroxyl groups have a higher reactivity than the secondary ones due to lower steric impediment (Chen, 2017).

$\mathrm{X}$-ray diffraction studies have shown that cellulose macromolecules in their crystalline structure have a regular and orderly arrangement, leading to a density of $1.588 \mathrm{~g} / \mathrm{cm}^{3}$. Conversely, in the amorphous regions, there are greater distances among the molecular chains because of the wide and irregular disposition of the macromolecules and as a result, the density of the cellulose in the amorphous regions is lower, i.e., $1.5 \mathrm{~g} / \mathrm{cm}^{3}$. Generally, the percentage of crystalline structure in cellulose ranges between 30 to 80\% (Chen, 2014; Bonechi et al., 2017).

The amorphous region of the cellulose is the most exposed part of the molecule, and is first to be attacked by cellulase enzyme leading to the hydrolysis of the molecule. When cellulose is completely hydrolyzed, Dglucose (a monosaccharide) is produced, whereas through partial hydrolysis, a disaccharide (cellobiose) and smaller polysaccharides are formed (with $\mathrm{n}$ values ranging between 3 and 10) (Bonechi et al., 2017). On the contrary, the crystalline part is hydrophobic in nature, i.e., does not absorb water and therefore, it needs to be subjected to a set of treatments called mercerization (from the name of the English dye and fabric chemist John Mercer who conceived the process in 1844) in order to obtain a hydrophilic cellulose.

Overall, in the last two centuries, due to its important properties and applications, cellulose has become an important raw material for the pulp and paper as well as chemical fiber industries. Furthermore, it currently plays an important role in various fields related to environmental protection, such as the application of cellulose water remediation to remove dangerous pollutants such as hydrocarbons and heavy metals (Arias et al., 2017; Tursi et al., 2018a and b; Tursi et al., 2019).

\subsection{Hemicellulose}

Hemicellulose is one of the major constituents of plant cell walls and consists of heterogeneous branched polysaccharides. It is strongly linked to the surface of cellulose microfibrils. The content and structure of hemicellulose are different depending on the type of plant (Bala et al., 2016). The various sugar units are arranged with different substituents and in different proportions. Hemicellulose decomposes thermally between 180 ${ }^{\circ} \mathrm{C}$ and $350{ }^{\circ} \mathrm{C}$, thereby producing non-condensable gas, coal, and a variety of ketones, aldehydes, acids, and furans (Carpenter et al., 2014).

In nature, hemicellulose is amorphous and has adhesive properties, with a high tendency to toughen when it is dehydrated. While cellulose is composed by glucose units linked by $\beta$-1,4-glycosidic bonds, hemicellulose almost entirely consists of sugars with five carbon atoms (xylose and arabinose) (Fig. 6) and six carbon atoms (glucose, galactose, mannose, and rhamnose) with an average molecular weight of $<30,000$ (McKendry, 2002a; Jindal and Jha, 2016; Bonechi et al., 2017). The different groups of molecules making up hemicellulose include xylans, mannans, galactans, and arabinogalactans.

\subsubsection{Xylans}

Xylans are polysaccharides possessing a structural function in plant cell 


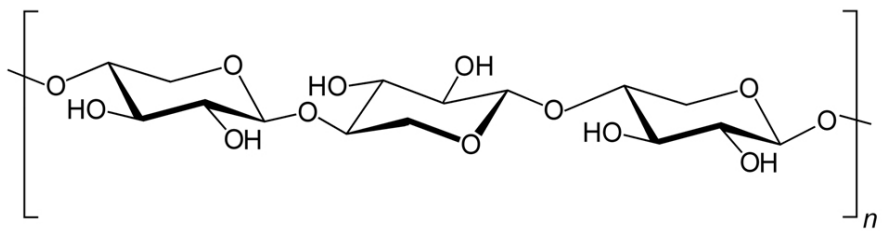

Fig. 6. The structural formula of hemicellulose.

walls. The main chain of xylan is similar to that of cellulose, however, it is composed of D-xylose (instead of D-glucose) as monomeric unit with traces of L-arabinose (Bajpai, 2009). Xylans are characterized by a main backbone formed by $\beta-1.4$ linkages between d-xylose units and related branches (Fig. 7) (Madeira et al., 2017).

The nature of the ramification of the main chain is variable: branches consisting of L-arabinofuranose linked to the $0-3$ positions of D-xylose residues and of D-glucuronic acid, acetyl esters or 4-O-methyl-D-glucuronic acid linked to the $0-2$ positions. Other groups could be linked to other substituents such as ferulate groups (Schaechter, 2009). Their abundance and composition within plant cells depend on the origin of the plant. A relationship between the chemical structure of xylans and their botanical origins has already been established (Bajpai, 2009; Chen, 2014).

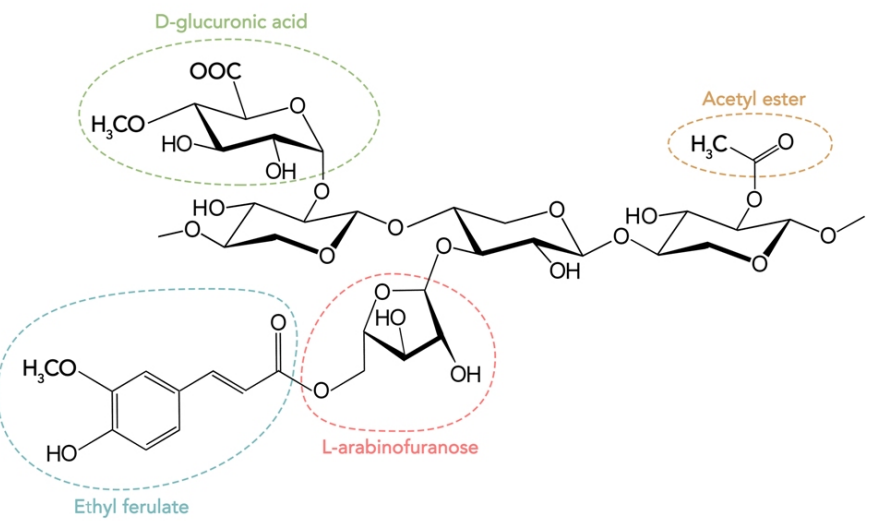

Fig. 7. The structural formula of xylans and derivates.

\subsubsection{Mannans}

Hemicellulose is mainly made up of mannans. The mannan compounds include mannan, galactomannan, glucomannan, glucuronic acid mannan, etc. (Fig. 8). Mannans are composed of mannose residues connected by $\beta-(1 \rightarrow 4)$ bonds while the galactomannans consist of galactose units bound with a $\beta$ $(1 \rightarrow 6)$ bonds (Amidon et al., 2008). The main chain of glucomannan is composed of glucose and mannose units (the hydroxyl group of mannose can also be acetylated), linked by $\beta-(1 \rightarrow 4)$ bonds, with a ratio of $1: 3$, and a galactose residue as branched chain. The glucuronic acid, which is predominant in the cell wall, is made up of mannose and glucoronic acid residues linked by $\beta-(1 \rightarrow 4)$ and $\beta-(1 \rightarrow 2)$ bonds in the main chain, respectively (Chen, 2014).

\subsubsection{Galactans and arabinogalactans}

The backbone of galactans is composed of galactose residues connected by $\beta-(1 \rightarrow 4)$ bonds while galactose residues, as side chain, are attached to the O-6. Arabinogalactan is a polysaccharide, particularly abundant in larch bark (Larix occidentalis). It has a skeleton consisting of galactan with lateral chains made of glucose and arabinose. Galactose and arabinose coexist in a molar ratio of

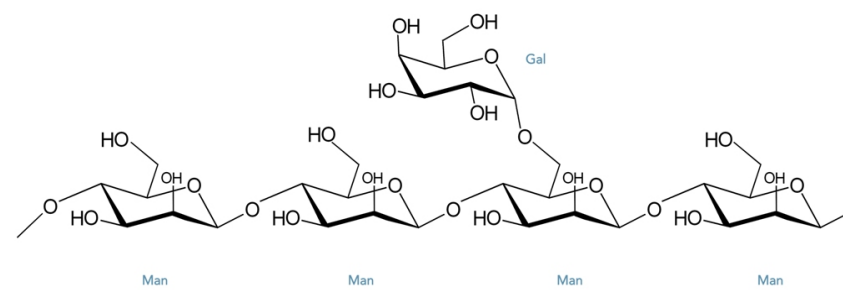

Galactomannan

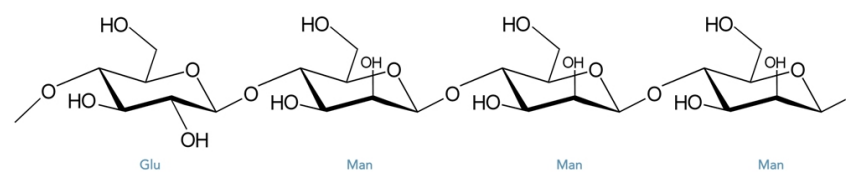

Glucomannan

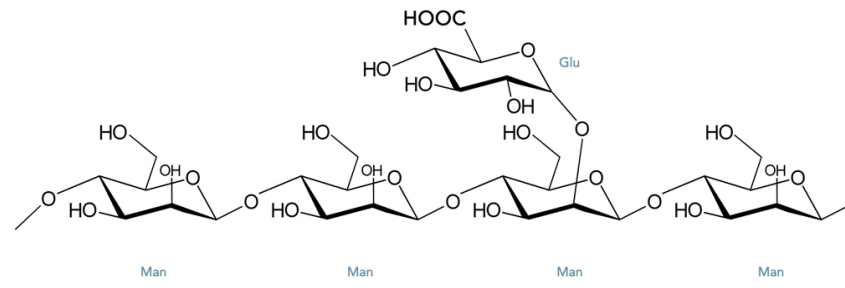

Glucuronic acid

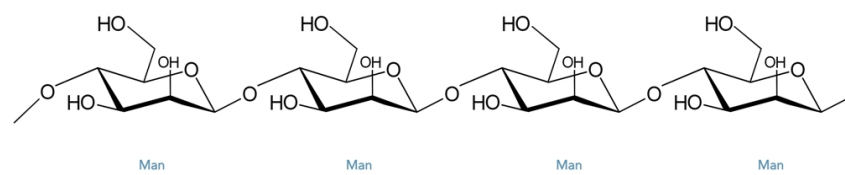

Mannan

Fig. 8. The structural formula of mannans and derivates.

6:1. Furthermore, ferulic acid may be linked to some arabinose and galactose residues (Amidon et al., 2008). The most common arabinogalactan include galactose residues (which may also be terminal) linked to O-3 or O-6 positions of the main chain and arabinofuranose residues linked to $\mathrm{O}-3$ or $\mathrm{O}-5$ positions. On the other hand, other types of arabinogalactan have galactose residues bound to O-4 or O-3 positions and arabinofuranose residues linked by an O-5 bond (Chen, 2014).

\subsection{Lignin}

Lignin is also contained in plant cell walls, with the function of binding, cementing, and putting the fibers together in order to enhance the compactness and resistance of the plant structure. Lignin is also recognized for its encrusting effect, as it covers the fibers. Therefore, in order to extract cellulosic fibers from plant materials, lignin degradation is essential.

The lignin content varies according to plant species $(25-30 \%$ up to values around $50 \%$ for very hard woods such as ebony) and age; annual 
plants containing about $10-12 \%$. Its elemental composition is approximately $61-65 \%$ carbon, $5-6 \%$ hydrogen, and the remaining is oxygen (Fromm et al., 2003).

The term lignin denotes a complex amorphous aromatic polymer with a three-dimensional network, composed of phenylpropane units linked together. The monomeric units are held together by different ways: through oxygen bridges between two propyl and phenyl groups, between a phenyl and a propyl group, or through carbon-carbon bonds between the same groups. In particular, this macromolecule is formed through the radical oxidative polymerization of three hydroxycinnamyl alcohols representing the basic structural monomers: $\mathrm{p}$ phenyl monomer (type $\mathrm{H}$ ), guaiacyl monomer (type $\mathrm{G}$ ) and siringyl monomer (type S), deriving from coumarinic, coniferyl and synapyl alcohol, respectively (Fig. 9). These compounds differ from each other due to the different degrees of methoxylation (Xu et al., 2005).

Furthermore, in the lignin structure, there are many polar groups and hydroxyl groups allowing the establishment of strong intramolecular and intermolecular hydrogen bonds. These in turn make lignin insoluble in any solvents except alkaline solutions. Through condensation reactions, lignin is split into soluble and insoluble lignin, with the latter forming a precipitate.

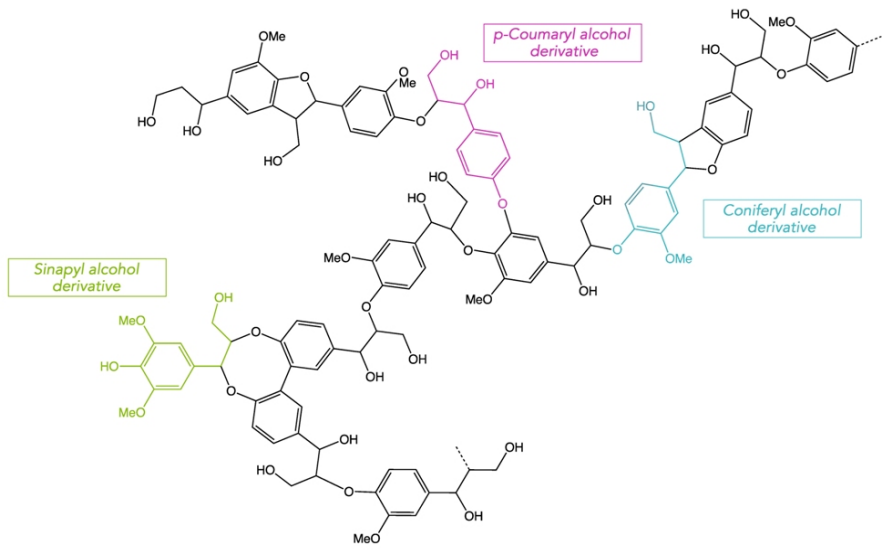

Fig. 9. The structural formula of lignin and its precursors.

The softening temperature of dry lignin ranges from 127 to $129^{\circ} \mathrm{C}$, however as the molecular weight of lignin grows, the softening temperature increases as well. Furthermore, the water contained inside the molecules acts as plasticizer, leading the softening temperature to decrease with an increase in the water content (Chen, 2014).

The modification of the cell wall by lignin infiltration is called lignification, a phenomenon leading to high mechanical resistance to the structure. Other than possessing greater mechanical resistance, lignified membranes become less swollen than cellulosic membranes, because the dipole -OH- cellulose groups are largely saturated by lignin. Overall, given the considerably high global availability of lignin, i.e., around 300 billion tons, with an annual increase of about 20 billion tons (Hodásová et al., 2015), development of innovative technologies for lignin valorization is essential.

In the last decade, the pulp and paper industry alone has produced approximately 50 million tons of extracted lignin (Wells and Ragauskas, 2016). Nevertheless, only 1 million tons of lignin from this sector has been used for the production of various value-added products, while the remaining has been burnt as low value fuel; lignin has a greater calorific value compared to lignocellulose biomass (Xie et al., 2016).

\subsubsection{Lignin valorization: value-added products}

Recently, scientific research has focused on improving lignin conversion processes, in order to use it as raw material for the production of high valueadded products, rather than burning it, such as dispersants (for building sector, enhanced oil recovery, production of printing ink, etc.), emulsifiers (as bitumen additives), precursors (for the production of vanillin, benzene, toluene and xylene, etc.), and finally for the production of various types of bio-based polymers, such as biocomposites, bioplastics, binders, additives, etc. (Rana et al., 2018)

The efficiency of separating polymers, including lignin, from the cell walls of lignocellulosic biomass is a crucial parameter, since it drives the biomass conversion rate in the final product (Hodásová et al., 2015). Yields and costs vary according to the type of biomass, the separation process, and the treatment times. Different methods are used to separate lignin from lignocellulosic biomass and are classified according to the applied process, i.e., steam explosion, kraft, organosolv, soda, lignosulfonates, and pyrolytic lignin (Wang et al., 2013). Alkaline and acidic procedures are the most efficient methods for lignin extraction. Furthermore, the organosolv process, which uses mixtures of alcohol and water at a temperature of about $200{ }^{\circ} \mathrm{C}$, represents another very effective method for this purpose (Welker et al., 2015). The extracted or separated lignin can be used as an unchanged macromolecule or it can be further modified, through processes of depolymerization (or fragmentation), into simpler and more usable forms. In some cases, after depolymerization, other methods such as reductive and oxidative conversion, functionalization of hydroxyl groups, and introduction of other functional groups are used for the production of several high value-added bio-based products (Laurichesse and Avérous, 2014; Welker et al., 2015; Abejón et al., 2018).

Nevertheless, depolymerization is the most challenging step in the conversion of lignin into valuable products (Kosa and Ragauskas, 2012 Xie et al., 2016). It can be performed by biological, chemical, and, thermochemical treatments, as well as by using homogeneous and heterogeneous catalysis, leading to the fractionation of aromatic compounds into simpler structures at the end of treatment (Xie et al., 2016).

Chemical depolymerization/fragmentation occurs could be conducted different processes: (1) pyrolysis, (2) hydrogenation, (3) hydrolysis, (4) oxidation, and (5) gasification. The choice of process and the fragmentation efficiency depend mainly on the type of lignin used (Pandey and Kim, 2011; Welker et al., 2015). Biological methods have also been considered for the depolymerization of lignin through (1) enzymatic oxidation or (2) microbial conversion with the use of microbes, bacteria, fungi, and termites capable of decomposing biomass to perform their metabolic functions (Sanchez, 2009; Welker et al., 2015).

In general, the value-added products derived from lignin, can be split into three main groups: biofuels, macromolecules, and aromatics (Smolarski, 2012), which could be used by different sectors as illustrated in Table 2.

Table 2.

Lignin-derived value-added products (Hodásová et al., 2015; Rana et al., 2018).

\begin{tabular}{lll}
\hline Sector & Products & Type of lignin \\
\hline \multirow{5}{*}{ Biofuels } & (I) Bio-oil from pyrolysis and & (I) Lignosulfonates \\
& $\begin{array}{l}\text { liquefaction } \\
\text { (II) Biodiesel via Fischer-Tropsch } \\
\text { process } \\
\text { (III) Syngas from gasification }\end{array}$ & $\begin{array}{l}\text { (II) Organosolv } \\
\text { (IV) Pyrolytic }\end{array}$ \\
& (I) Phenolic/aromatics compounds & (I) Lignosulfonates \\
& (II) Kraft \\
Chemicals & (III) Emulsifiers & (III) Organosolv \\
& (IV) Flocculants & (IV) Soda \\
& (V) Steam \\
& (I) Biocomposites and bioplastics & explosion \\
(II) Carbon fibers & (I) Lignosulfonates \\
Materials/polymers & (III) Activated carbons & (II) Kraft \\
& (IV) Adsorbents & (III) Organosolv \\
& (V) Binders & (IV) Soda \\
& (VI) Additives for cement/paints & \\
& (I) Pesticides & \\
(II) Herbicides & (I) Kraft \\
(III) Water treatment agents & (II) Organosolv \\
(IV) Soil and dust agents & \\
\hline \multirow{5}{*}{ Phvironmental } & (I) Antioxidants & (I) High grade \\
& (II) Cosmetics & (derived from Kraft \\
& (III) Prebiotics & \\
\hline & & lignin) \\
& &
\end{tabular}




\subsection{Starch}

Starch represents the main reserve of carbohydrates in vegetable tubers and seeds. It is found in the form of granules (of different morphological appearances depending on plant species), each containing several million of amylopectin molecules and a large number of amylose molecules.

In nature, starch can be found in two forms: approximately $25-27 \%$ as amylose, which is soluble in hot water and approximately $73-75 \%$ as amylopectin, which is water-insoluble. Amylopectin (without amylose) can be isolated from "waxy" corn starch, while amylose (without amylopectin) is isolated by hydrolysis of amylopectin with pullulanase (Vorwerg et al., 2002).

The empirical formula of starch is $\left(\mathrm{C}_{6} \mathrm{H}_{10} \mathrm{O}_{5}\right)_{\mathrm{n}}$, where $n$ is a variable number ranging from a hundred to a few thousand; indicating the residues of $\alpha$-Dglucose units (in the ${ }^{4} \mathrm{C}_{1}$ conformation) that are linked together to create the polymers (Edwards et al., 2003).

\subsubsection{Amylose}

Amylose molecules are single non-branched chains with 500-20,000 $\alpha-(1-$ 4) D-glucose units, adopting a helical structure (Fig. 10). Amylose occurs in different forms of A, B, and V. The A and B forms both show stiff left-handed helices with six glucose units per turn. The only characteristic that differentiates the two forms from each other has to do with the different packing of the starch helices. Single helical amylose has hydrogen boding betweem O-2 and O-6 atoms on the external surface of the helix with only the ring oxygen pointing inward.

The $\mathrm{V}$ form of amylose is generated by co-crystallization processes with compounds including iodine, alcohols, fatty acids and dimethyl sulfoxide (Winger et al., 2009). The hydrogen bonds among aligned chains causes retrogradation and release of the water (syneresis), allowing the aligned chains to form a double-stranded hydrophobic structure resistant to amylases. This is the reason why amylose gives resistance to starch.

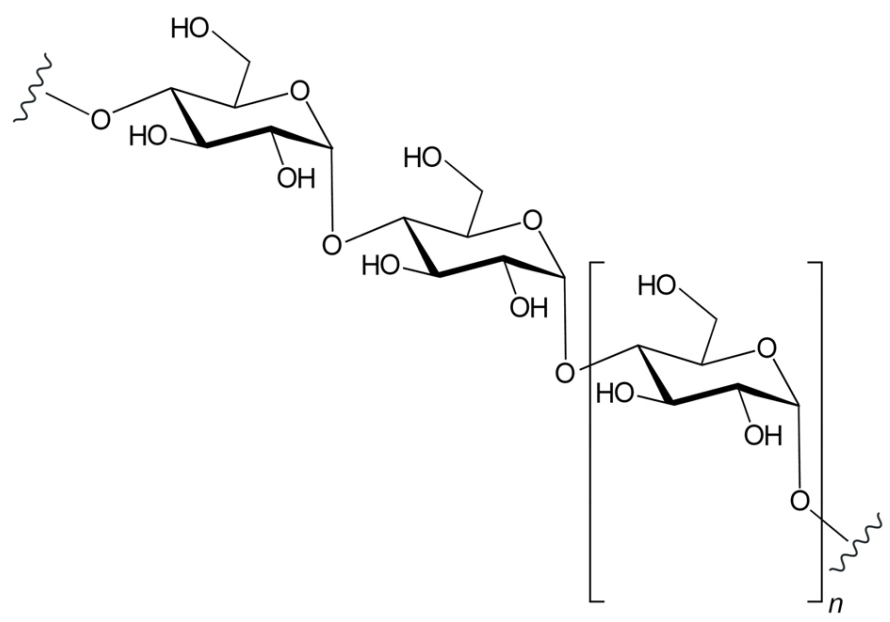

Fig. 10. The structural formula of amylose.

\subsubsection{Amylopectin}

As the main component of starch, amylopectin is one of the largest molecules found in nature. It is composed of linear chains of $\alpha$-Dglucopyranosyl units bound by $(1 \rightarrow 4)$ bonds, while the branching point is connected by $\alpha$ - $(1 \rightarrow 6)$ bonds (Fig. 11) (Winger et al., 2009).

Amylopectin is composed of three different types of chains: a larger number of "external" non-branched chains (called A-chains) than internal branched chains (called B-chains). The third chain (called C-chains) is the only one including a single reduction group. The average length of the A-chains is in the range of 13-23 residues, while the B-chains have a higher average length of about 23-25 residuals.
Several studies demonstrate that depending on the sources, the relative molecular weight of amylopectin, is between $10^{7}$ and $10^{8}$ daltons (Singh et al., 2003; Waniska et al., 2016), in particular, Buléon et al. (1998) estimated that the number of amylopectin chains in a single starch granule stands at $5.4 \times 10^{7}$.

The most important reaction that amylopectine can undergo is certainly the hydrolysis, which occurs in the process of seed germination, involving the dissolution of the $\alpha(1 \rightarrow 4)$ bonds by the $\alpha$ - and $\beta$-amylase enzymes and the consequent production of dextrins (small segments containing $(1 \rightarrow 6)$ bonds). Dextrins will subsequently be cleaved by other enzymes known as dextrinase completing the digestion of starch to glucose (Winger et al., 2009).

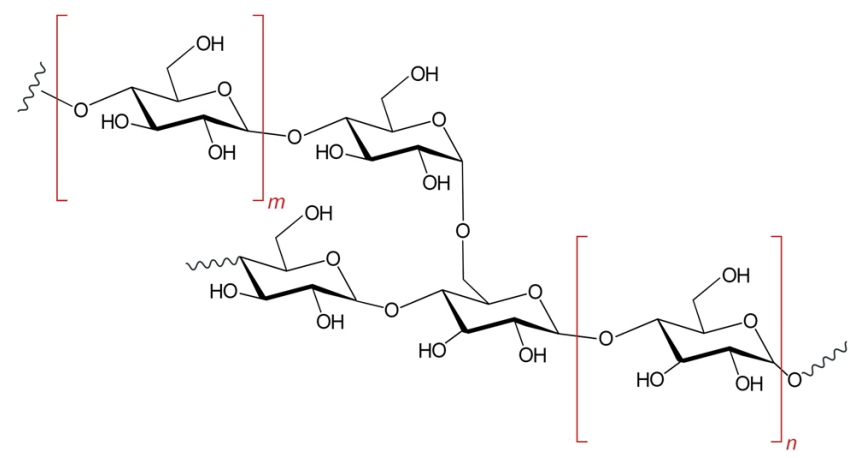

Fig. 11. The structural formula of amylopectine.

\subsection{Minor organic components}

Several studies have shown that different biomass substrates can contain important quantities of minor organic components, which may influence the treatment processes. These are listed below as follows (Vassilev et al., 2012):

- $2-40 \%$ of lipids, $6-71 \%$ of proteins, and up to $6 \%$ of nucleic acid in algae (Demibars, 2010).

- 2-4\% of acetyls in some straws and flax (Tamaki, 2010).

- $1-4 \%$ of uronic acids in pine, eucalyptus, and sorghum grass.

- Up to $10 \%$ of proteins in pine, reeds, spruce, birch, and maize (Huber et al., 2006; Tamaki and Mazza, 2010).

\subsection{Inorganic matter}

In general, biomass also contains inorganic substances (ash) in traces, whose quantity varies according to the type of raw material (Alaswada et al., 2015). Among these, the common elements are metals such as calcium, sodium, potassium, magnesium, phosphorus, silicon, aluminum, and iron (Werkelin et al., 2005).

In addition to various species of crystallized minerals, the inorganic matter (on average around 7\%, DW) also contains different amorphous phases of natural origin. Normally, the most common solid residues that exist in biomass are water-soluble residues such as chlorides, sulphates, oxalates, nitrates, carbonates, and both organic and inorganic amorphous materials.

During some pretreatment processes, biomass is dried at $105{ }^{\circ} \mathrm{C}$ and further heated in furnaces at temperatures reaching $750{ }^{\circ} \mathrm{C}$. Under such circumstances, elements such as carbon, hydrogen, oxygen, nitrogen, and sulfur evaporate as gaseous compounds due to their chemical characteristics, while the ash residue remains, containing mineral elements in their oxide forms (Chen, 2014)

\subsection{Other elements in biomass}

In lignocellulosic materials and in plants (except for carbon, hydrogen, oxygen, and other basic elements), there are other minority components in 
small quantities, i.e., pigments, waxes, alkaloids, and terpenes.

\subsection{Fluid matter}

The fluid material is an aqueous solution contained in biomass. It contains various cation and anion species. The moisture content of biomass is normally in the range of $10-60 \%$ but in some types of raw biomass, it can even reach as high as $80-90 \%$. The fluid matter content depends on the starting composition of biomass and observed percentage values can be related to high water content in living cells. Fast-growing crops, for example, possess high water contents and typical elements related to vegetal physiology, such as $\mathrm{Na}, \mathrm{Ca}, \mathrm{K}, \mathrm{Mg}, \mathrm{N}$, $\mathrm{P}, \mathrm{Cl}$, and S (Vassilev et al., 2012).

\section{Biomass classification}

Due to the substantial differences in term of variety and quantity of biomass, and their different compositional characteristics, there is no univocal way of classification of biomass, so they can be grouped differently, depending on purpose and scope.

According to origin, function and final products, generally biomass is classified in two ways:

I. Categorization based on types of biomass existing in nature (according to ecology or type of vegetation);

II. Categorization based on the use and application of biomass as feedstock.

The former is the most used classification splitting biomass into different groups (Table 3):

I. Wood and woody biomass

II. Herbaceous biomass

III. Aquatic biomass

IV. Animal and human waste biomass

V. Biomass mixtures

Typical chemical composition of different biomass groups are tabulated in Table 4.

\subsection{Wood and woody biomass}

The woody biomass includes different components, mainly consisting of carbohydrates and lignin. Generally, this category consists of materials such as trees and roots residues, bark and leaves of woody shrubs both above and below ground, which can be converted into energy by direct combustion (or gasification) or through numerous conversion processes (Vassilev et al., 2012).

Typically, the biomass used for the production of energy and fuel comes from four primary sources:

I. Production residues;

II. Residues of non-merchant timber;

III. Post-consumption wood wastes;

IV. Urban and agricultural wastes.
Table 3.

Biomass classification: groups, varieties, and species (Vassilev et al., 2012).

\begin{tabular}{ll}
\hline Biomass group & Varieties and species \\
\hline Wood and woody biomass & $\begin{array}{l}\text { Coniferous or deciduous; Angiospermous or } \\
\text { gymnospermous; Stems, branches, foliage, } \\
\text { bark, chips, lumps, pellets, briquettes, sawdust, } \\
\text { sawmill and others from various wood species. }\end{array}$ \\
& $\begin{array}{l}\text { Grasses and flowers (alfalfa, arundo, bamboo, } \\
\text { bana, brassica, cane, cynara, miscanthus, } \\
\text { switchgrass, timothy, others); straws (barley, } \\
\text { bean, flax, corn, mint, oat, rape, rice, rye, } \\
\text { sesame, sunflower, wheat, others); other } \\
\text { residues (fruits, shells, husks, hulls, pits, pips, } \\
\text { grains, seeds, coir, stalks, cobs, kernels, } \\
\text { bagasse, food, fodder, pulps, cakes, etc.). }\end{array}$ \\
Herbaceous biomass & $\begin{array}{l}\text { Marine or freshwater algae; macroalgae (blue, } \\
\text { green, blue-green, brown, red) or microalgae; } \\
\text { seaweed, kelp, lake weed, water hyacinth, etc. }\end{array}$ \\
Aquatic biomass & Bones, meat-bone meal; various manures, etc. \\
\hline Animal and human waste biomass
\end{tabular}

Woody biomass is currently the most important renewable energy source in the world. In 2010, the global use of woody biomass led to an energy production of approximately $30 \mathrm{EJ}$ while $16 \mathrm{EJ}$ was related to household fuelwood and $14 \mathrm{EJ}$ to industrial use of woody biomass (Lauri et al., 2014).

\subsection{Herbaceous biomass}

The European standard EN 14961-1, which classifies solid biofuels, suggests the following definition for herbaceous biomass (Chum et al., 2011):

"Herbaceous biomass is from plants that have a non-woody stem and which die back at the end of the growing season. It includes grains or seeds crops from food processing industry and their by-products such as cereal straw".

Generally, herbaceous biomass resources belong to one of the following two main groups, i.e., agricultural residues and energy crops.

I. Agricultural residues are by-products of food, fibers, or food industries. Some of these by-products are collected for different enduses, such as animal feed. In any cases, these residues are not fully monitored and their availability across different regions and their potential applications as bioenergy are not fully clear.

II. Energy crops, on the other hand are exploited only in the bioenergy sector.

Efficient exploitation of this biomass can lead to positive impacts at regional level, by replacing fossil fuels and creating new jobs and revenues.

Table 4.

Typical chemical composition of different biomass groups (wt.\%) (Vassilev et al., 2010).

\begin{tabular}{|c|c|c|c|c|c|c|c|c|c|}
\hline Biomass group & $\mathrm{C} *(\%)$ & $\mathbf{O}(\%)$ & $\mathbf{H}(\%)$ & $\mathrm{S}(\%)$ & $\mathbf{N}(\%)$ & VM (\%) & $\mathrm{FC}(\%)$ & $\mathbf{M}(\%)$ & $\mathbf{A}(\%)$ \\
\hline Wood and woody biomass & $49-57$ & $32-45$ & $5-10$ & $<1-1$ & $<1-1$ & $30-80$ & $6-25$ & $5-63$ & $1-8$ \\
\hline Herbaceous biomass & $42-58$ & $34-49$ & $3-9$ & $<1-1$ & $<1-3$ & $41-77$ & $9-35$ & $4-48$ & $1-19$ \\
\hline Aquatic biomass & $27-43$ & $34-46$ & $4-6$ & $1-3$ & $1-3$ & $42-53$ & $22-33$ & $8-14$ & $11-38$ \\
\hline Animal and human waste biomass & $57-61$ & $21-25$ & $7-8$ & $1-2$ & $6-12$ & $43-62$ & $12-13$ & 3-9 & 23-34 \\
\hline Biomass mixtures & $45-71$ & $16-46$ & $6-11$ & $<1-2$ & $1-6$ & $41-79$ & $1-15$ & $3-38$ & $3-43$ \\
\hline
\end{tabular}

* Abbreviations: Carbon (C), Oxygen (O), Hydrogen (H), Sulfur (S), Nitrogen (N), Volatile matter (VM), Fixed carbon (FC), moisture (M), and ash (A) content. 


\subsection{Aquatic biomas}

The term aquatic biomass includes macroalgae, microalgae, and emerging plants (Di benedetto, 2011):

I. Macroalgae are multicellular organisms that can quickly reach up to 60 $\mathrm{m}$ in length. They are mainly used for food production and hydrocolloids extraction.

II. Microalgae are microscopic organisms, which can be subdivided into the following subgroups: diatoms, green and golden algae. Diatoms are unicellular and brown algae, generally only a few $\mu \mathrm{m}$ in size; they represent one of the main components of aquatic microflora and one of the largest source of biomass on earth. Green algae are particularly abundant in freshwater resources. The main product obtained from these algae is starch, although oils can also be produced. Golden algae are similar to diatoms and produce oils and carbohydrates.

III. Emerging plants grow partially submerged in marshes and swamps.

In nature, there are about 55,000 species and over 100,000 strains of brackish water, freshwater, and terrestrial algae. The great advantage of using these simple organisms is their ability to convert sunlight, water, and $\mathrm{CO}_{2}$ into a wide variety of metabolites and chemicals that end up in algal biomass (Vassilev and Vassileva, 2016).

Currently, aquatic biomass is considered as an ideal raw material for the production of third-generation biodiesel, as it is not in competition with food crops, along with the advantage of producing considerably larger amounts of biomass per hectare compared to land crops. However, there are still considerable economic and technological challenges to be overcome before such biofuels could be effectively commercialized. Moreover, it should be noted that there are many parameters influencing the performance of aquatic biomass such as levels of irradiation, $\mathrm{CO}_{2}$ and $\mathrm{O}_{2}$ concentrations, temperature, pH, salinity, and nutrients (Strezov and Evans, 2014).

\subsection{Animal and human waste biomass}

The most common sources are bones, meat meal, various types of animal manures, and human dung (Vassilev et al., 2012) (Table 3). In the past, these wastes were recovered and sold as fertilizers or simply used on agricultural land, but the introduction of more stringent environmental regulations on pollution, health, and odor concerns, has led to proper waste management. Anaerobic digestion is the most convenient method to convert this waste into useful products. For instance, biogas, as a bioenergy product of the process, could be used to generate electricity in turbines and internal combustion engines or could be burned directly for cooking or to heat rooms and water (Horan, 2018).

\subsection{Biomass mixtures}

In some cases, when several substrates belonging to different classes, mentioned above, are in mixed form, they are classified in this category.

\section{Energy from biomass}

As mentioned earlier, biomass could be a source of renewable energy and by replacing fossil fuels could substantially limit their environment impacts. Biomass, through treatment and conversion processes, can be converted into different types of energy carriers. The parameters that determine the choice of the production process are diverse but the most important ones include the renewable end-product required, the quality and quantity of biomass, and the cost of the process (Dalena et al., 2017).

Biomass can be converted into two main types of energy carriers (McKendry, 2002a):

I. Electrical/heat energy;

II. Transportation fuels;

The following physicochemical characteristics of biomass play a crucial role in directing the available feedstock into both or either of these domains:

- Moisture content (intrinsic and extrinsic);
- Caloric value

- Proportions of fixed carbon and volatile substances;

- Ash content;

- Alkali metal content;

- Cellulose/lignin ratio

The first five properties largely influence the conversion processes of dry biomass, while the first and the last one are essential for the conversion processes of wet biomass (McKendry, 2002b).

With regard to lignocellulosic biomass, it should undergo pretreatment processes in order to become suitable for conversion into transportation fuels and value-added co-products (Agbor et al., 2011; Dalena et al., 2017). In fact, pretreatment is aimed at simultaneously decreasing the crystallinity index of cellulose and increasing its available surface area by removing the ayers of lignin and hemicellulose, leading to a more efficient cellulose hydrolysis (Mosier et al., 2005; García et al., 2011; Zhao et al., 2012).

Pretreatment methods used for lignocellulosic materials are classified into mechanical, chemical, chemical/mechanical, and biological methods (Table 5).

\section{Conversion technologies}

The processes involved in biomass conversion into energy are commonly classified as follows (Table 6):

I. Thermo-chemical conversions;

II. Biochemical conversions;

III. Physico-chemical conversions.

\subsection{Thermo-chemical conversion of biomass}

In thermo-chemical conversion processes, energy is produced by applying heat and chemical processes. There are four thermo-chemical conversion processes, i.e., combustion, pyrolysis, gasification, and liquefaction.

\subsubsection{Combustion}

The combustion processes produce approximately $90 \%$ of the total renewable energy obtained from biomass. Combustion plants can operate on different types of biomass, i.e., wood, dry leaves, hard vegetable shells, rice husk, dried animal dung, etc. (Lebaka, 2013).

In the combustion process, biomass and oxygen are combined in a high temperature environment to form carbon dioxide, water vapour, and heat (Eqs. 1 and 2).

Biomass + Oxygen $\rightarrow$ Carbon Dioxide + Water + Heat

The approximate chemical equation for biomass combustion is:

$\mathrm{CH}_{1.44} \mathrm{O}_{0.66}+1.03 \mathrm{O}_{2} \rightarrow \mathrm{CO}_{2}+0.72 \mathrm{H}_{2} \mathrm{O}+$ Heat

The amount of generated heat depends on many factors but mainly on the type of biomass used in the process, although the average thermal energy produced is $20 \mathrm{MJ} / \mathrm{kg}$ of biomass (Nussbaumer, 2003).

As showed by the Equations 1 and 2, the combustion process is an exothermic chemical reaction, i.e., the biomass is burnt in the presence of air with the subsequent release of chemical energy that could be converted into mechanical and electrical energy (Lebaka, 2013; Kaushika et al. 2016).

Combustion process is carried out inside combustion chambers at the temperatures ranging between 800 to $1000{ }^{\circ} \mathrm{C}$. An essential requirement of the dry biomass used is its moisture content, which should be less than $50 \%$. Typically, biomass combustion plants (which use wood and forest residues as fuel) generate between 20 to $50 \mathrm{MWe}$, with related electrical efficiencies of $25-30 \%$. Further developments of these systems and the application of fluidized bed systems and advanced gas cleaning have resulted in increased 
Table 5.

Main pretreatment methods used for lignocellulosic materials.

\begin{tabular}{|c|c|c|}
\hline Pretreatment category & Type & Short description \\
\hline \multirow{2}{*}{ Mechanical } & Milling & Use of techniques and mechanical devices to reduce the biomass in size. \\
\hline & Ultrasonic & Use of ultrasonic techniques and apparatus to break down biomass into smaller molecules. \\
\hline \multirow{7}{*}{ Chemical } & Liquid hot water & $\begin{array}{l}\text { Pretreatment performed with water at elevated temperatures in the range of } 150-230^{\circ} \mathrm{C} \text { and high pressures for lignin, hemicellulose, } \\
\text { and cellulose hydrolysis (Harmsen et al., 2010). }\end{array}$ \\
\hline & Weak acid & $\begin{array}{l}\text { Dilute acid is sprayed onto the raw material and the mixture is held at } 160-220^{\circ} \mathrm{C} \text { for short periods to achieve lignin, hemicellulose, } \\
\text { and cellulose hydrolysis ( Chen et al., 2017). }\end{array}$ \\
\hline & Strong acid hydrolysis & $\begin{array}{l}\text { Strong concentrated acids (such as } \mathrm{H}_{2} \mathrm{SO}_{4} \text { and } \mathrm{HCl} \text { ) are used for lignin, hemicellulose, and cellulose hydrolysis (Sun and Cheng, } \\
\text { 2002). }\end{array}$ \\
\hline & Alkaline hydrolysis & Calcium (or sodium) hydroxide and ammonia are used to reduce lignin content and remove some hemicellulose. \\
\hline & Organosolv & Organic solvent or organic solvent mixtures with water are used to remove lignin before cellulose enzymatic hydrolysis. \\
\hline & Oxidative & Oxidising agents such as $\mathrm{H}_{2} \mathrm{O}_{2}$, ozone, oxygen or air, are used for the delignification of cellulose. \\
\hline & $\begin{array}{l}\text { Room Temperature Ionic } \\
\text { Liquids (RTIL) }\end{array}$ & $\begin{array}{l}\text { Inorganic anions and organic cations are used for the separation of lignin and to increase the accessibility of cellulose under } \\
\text { environmental conditions and without the use of acidic or alkaline solutions (Imai et al., 2004). }\end{array}$ \\
\hline \multirow{5}{*}{ Chemical/Mechanical } & Steam explosion & $\begin{array}{l}\text { High pressure saturated steam is injected into a reactor filled with biomass and subsequently, with a sudden reduction in pressure, } \\
\text { the biomass undergoes an explosive decompression breaking lignin and degrading hemicellulose (Harmsen et al., 2010). }\end{array}$ \\
\hline & AFEX & $\begin{array}{l}\text { Liquid ammonia is used at high temperature and pressure in a reactor. Subsequently, a drastic reduction of the pressure is applied } \\
\text { leading to reduced lignin and hemicellulose contents while cellulose is de-crystallized (Teymouri et al., 2005; Harmsen et al., 2010). }\end{array}$ \\
\hline & & \\
\hline & $\mathrm{CO}_{2}$ & $\begin{array}{l}\text { High pressure } \mathrm{CO}_{2} \text { is injected into the batch reactor containing biomass. The pressure reduction generates an explosive } \\
\text { decompression improving the subsequent hydrolysis (Sun and Cheng, 2002). }\end{array}$ \\
\hline & $\begin{array}{l}\text { Mechanical/alkaline } \\
\text { pretreatment }\end{array}$ & $\begin{array}{l}\text { The process consists of a continuous mechanical pretreatment of lignocellulosic biomass with the addition of an alkali. The result is } \\
\text { a soluble fraction of lignin, hemicellulose, and other compounds in addition to the insoluble part of cellulose (Harmsen et al., 2010). }\end{array}$ \\
\hline Biological & Biological hydrolysis & $\begin{array}{l}\text { In a reaction batch, microorganisms (such as white and brown fungi) are used to degrade hemicellulose and lignin (Harmsen et al., } \\
\text { 2010). }\end{array}$ \\
\hline
\end{tabular}

Table 6.

Main conversion technologies and their corresponding products (Mesa et al., 2010; Lebaka, 2013; Portha et al., 2017).

\begin{tabular}{|c|c|c|c|}
\hline Process/Technology & & Feedstock & Usable end product \\
\hline \multirow{4}{*}{ Thermo-chemical conversion } & Combustion & $\begin{array}{l}\text { (I) Agricultural residues } \\
\text { (II) Woody residues } \\
\text { (II) Animal wastes }\end{array}$ & $\begin{array}{l}\text { (I) Heat } \\
\text { (II) Electricity }\end{array}$ \\
\hline & Pyrolysis & $\begin{array}{l}\text { (I) Agricultural residues } \\
\text { (II) Woody residues }\end{array}$ & $\begin{array}{l}\text { (I) Pyrolysis oil } \\
\text { (II) Producer gas } \\
\text { (III) Char }\end{array}$ \\
\hline & Gasification & $\begin{array}{l}\text { (I) Agricultural residues } \\
\text { (II) Woody residues }\end{array}$ & $\begin{array}{l}\text { (I) Producer gas } \\
\text { (II) Liquid fuels } \\
\text { (III) Char }\end{array}$ \\
\hline & Liquefaction & $\begin{array}{l}\text { (I) Agricultural residues } \\
\text { (II) Algal biomass }\end{array}$ & $\begin{array}{l}\text { (I) Fertilizer/biofuel } \\
\text { (II) Syngas } \\
\text { (III) Liquid fuels }\end{array}$ \\
\hline \multirow{2}{*}{ Biochemical conversion } & Anaerobic digestion & $\begin{array}{l}\text { (I) Animal wastes } \\
\text { (II) Sewage sludge }\end{array}$ & $\begin{array}{l}\text { (I) Liquid fuels } \\
\text { (II) Biogas } \\
\text { (II) Electricity }\end{array}$ \\
\hline & Fermentation & $\begin{array}{l}\text { (I) Agricultural residues } \\
\text { (II) Sugars } \\
\text { (III) Starch }\end{array}$ & (I) Liquid fuels (bioethanol) \\
\hline Physico-chemical conversion & Esterification/Transesterification & $\begin{array}{l}\text { (I) Vegetable oils } \\
\text { (II) Animal fats } \\
\text { (II) Waste oils }\end{array}$ & $\begin{array}{l}\text { (I) Liquid fuels } \\
\text { (II) Glycerol }\end{array}$ \\
\hline
\end{tabular}

Please cite this article as: Tursi A. A review on biomass: importance, chemistry, classification, and conversion. Biofuel Research Journal 22 (2019) $962-979$. DOI: 10.18331/BRJ2019.6.2.3 
electricity production from biomass, on a scale of 50-80 MWe, with electrical efficiencies of up to $30-40 \%$ (McKendry, 2002b). A typical scheme of the biomass combustion process is shown in Figure 12.

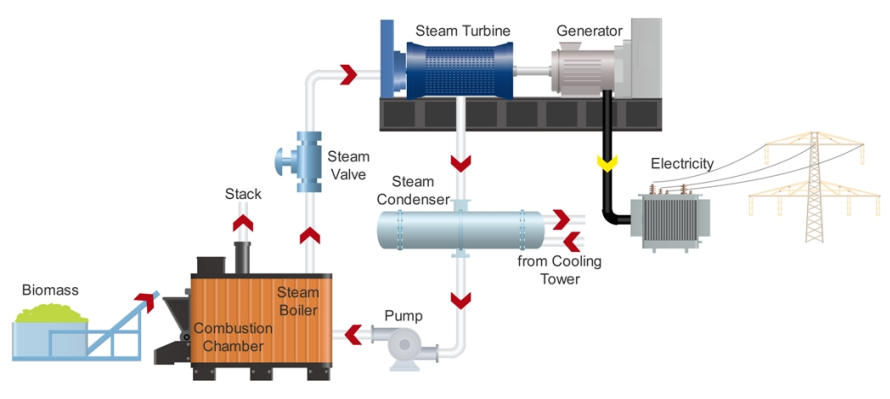

Fig. 12. Biomass combustion scheme.

\subsubsection{Pyrolysis}

Pyrolysis is the conversion process of specific biomass into liquid (bio-oil), solid (charcoal), and gaseous (combustible gas) products through partial combustion at temperatures around $500{ }^{\circ} \mathrm{C}$ and in the absence of oxygen (Lebaka, 2013). High temperatures allow the vaporization of the volatile components of the biomass producing gases, whose vapours are condensed into liquids by liquefaction. The liquid fuel resulting from this process can be stored and subsequently used for various heating and electricity generation applications. In addition to liquid fuels, the pyrolysis process also produces other combustible products such as charcoal, gas, and many other value-added chemicals (Kaushika et al., 2016).

The typical scheme of the biomass pyrolysis process is shown in Figure 13.

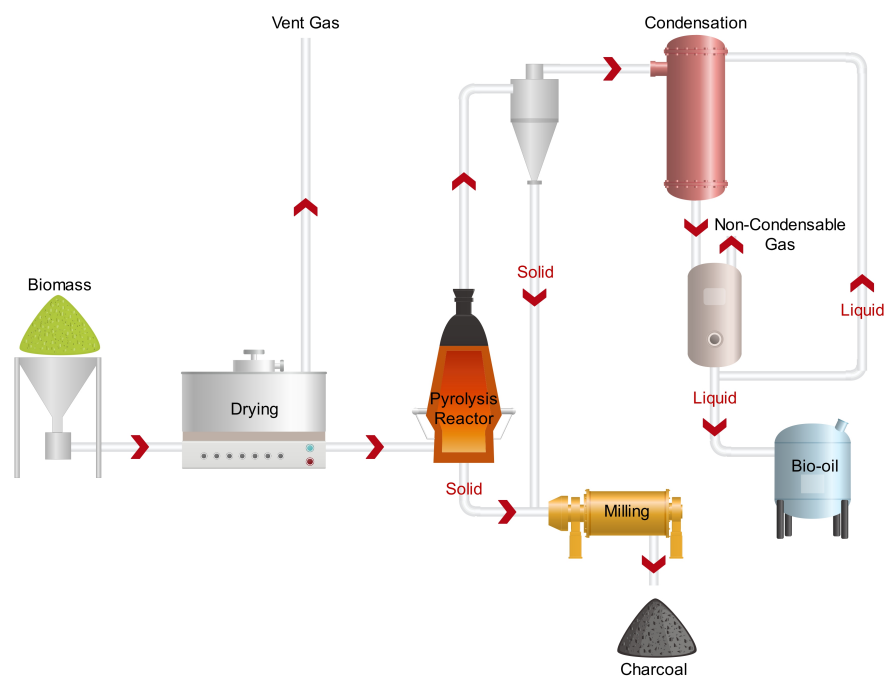

Fig. 13. Biomass pyrolysis scheme.

As mentioned earlier, simple pyrolysis systems are performed at temperatures below $600{ }^{\circ} \mathrm{C}$, while in industrial plants, where temperatures higher than $600-1000{ }^{\circ} \mathrm{C}$ are arched, the gas produced contains higher quantities of hydrogen. Obviously, these processes require more sophisticated systems and management as well (Di Blasi, 2008).

The pyrolysis process consists of four main steps taking place at different temperatures following the order presented below (Portha et al., 2017):

a. Drying of the incoming biomass at temperatures ranging between 100$120^{\circ} \mathrm{C}$; b. Distillation of the outlet gases, mainly $\mathrm{N}_{2}, \mathrm{CO}$, and $\mathrm{CO}_{2}$, acetic acid and methanol at $275{ }^{\circ} \mathrm{C}$;

c. Exothermic reactions occurring at temperatures between $280{ }^{\circ} \mathrm{C}$ and $350{ }^{\circ} \mathrm{C}$, thereby removing complex mixtures of chemical substances (i.e., ketones, aldehydes, phenols, esters), $\mathrm{CO}_{2}$, carbon monoxide (CO), methane $\left(\mathrm{CH}_{4}\right), \mathrm{C}_{2} \mathrm{H}_{6}$, and $\mathrm{H}_{2}$ by breaking the weakest chemical bonds;

d. Removal of all volatile compounds by evaporation at $350{ }^{\circ} \mathrm{C}$, with formation of higher proportions of $\mathrm{H}_{2}, \mathrm{CO}$, and carbon; the last one remains in the form of charcoal as residues.

Condensed liquids (tar, pyroleptic acid and derivatives) from the pyrolysis process can be separated. The approximate yield of the products from $100 \mathrm{~kg}$ of dry wood is: $30 \mathrm{~kg}$ of charcoal, $14 \mathrm{~m}^{3}$ of gas (calorific value of $10.4 \mathrm{MJ} / \mathrm{m}^{3}$ ), 7.6 L of wood oil and light tar, $1.4 \mathrm{~L}$ of methyl alcohol, 3 $\mathrm{kg}$ of pitch, $5.3 \mathrm{~L}$ of acetic acid, $0.8 \mathrm{~L}$ of esters, etc. (Damartzis and Zabaniotou, 2011).

There are different ways of carrying out the pyrolytic process affecting the production of bio-oil, syngas and carbonaceous residues:

I. Carbonization, the most ancient and known pyrolysis process, occuring at temperatures between 300 and $500{ }^{\circ} \mathrm{C}$ (Kaltschmitt, 2013). From this process, only a solid fraction (vegetable coal) is recovered.

II. Slow or conventional pyrolysis occurs at moderate temperatures around $500{ }^{\circ} \mathrm{C}$, through which approximately three fractions are obtained in equal proportions. Slow pyrolysis requires longer reaction and transformation times than fast pyrolysis due to low temperature and heating values.

III. Fast pyrolysis takes place at medium-low temperatures (from 500 to $650{ }^{\circ} \mathrm{C}$ ), in which the gasification reactions take place quickly and with short contact times, so that the intermediate compounds are reformed, bringing the production of the liquid fraction up to 70-80 wt.\% of the incoming biomass. Generally, this type of pyrolysis produces $60 \%$ of bio-oil, $20 \%$ of bio-coal, and $20 \%$ of gas.

IV. Flash pyrolysis is performed at temperatures higher than $650{ }^{\circ} \mathrm{C}$ with contact times of less than one second and favours the production of the gaseous fraction (efficiency reaching $80 \%$ ).

Currently, the pyrolysis process is mainly used for the production of the liquid fraction, i.e., the bio-oil, which can be used as fuel for energy production through co-generators. The use of bio-oil has considerable advantages including more competitive production cost compared to other biofuels, a balance of neutral $\mathrm{CO}_{2}$ emissions, and a high energy density if refined well (Kaltschmitt, 2013).

\subsubsection{Gasification}

The gasification process converts solid carbon materials (solid biomass) into a gas, called synthesis gas or syngas, mainly composed of $\mathrm{CO}$, hydrogen $\left(\mathrm{H}_{2}\right)$, and nitrogen $\left(\mathrm{N}_{2}\right)$. Syngas can be used as fuel to generate electricity, or as a basis for a large number of products in the petrochemical and refinery industries, such as methanol, ammonia, synthetic gasoline, etc. (Rahimpour et al., 2012)

The first gasification technologies were developed in the early decades of the twentieth century. There are different types of treatment and processes, but they all share some common characteristics. Of course, the dominant technology is the partial oxidation of the solid matrix at high temperatures, which produces a syngas consisting of $\mathrm{CO}$ and $\mathrm{H}_{2}$ in various ratios, whose combination accounts for more than $85 \%$ of the total volume, while the remaining gas includes $\mathrm{CO}_{2}$ and $\mathrm{CH}_{4}$ (Molino et al., 2016).

This treatment is a rather complex thermochemical process that can be carried out in a closed air-tight chamber under air suction or low air pressure relative to the atmospheric pressure. The gas produced by gasification is subsequently 'cleaned', to remove impurities and recover trace elements at once. This makes gasification a very interesting process thanks to the ability to remove all the pollutants from the syngas, in particular with regard to the materials with high contents of heteroatoms or impurities that cannot be treated with other procedures. For instance, through this technology, sulfur could generally be recovered in elementary form, while the purified gas 
could be used for chemicals production and/or electricity generation (Fig. 14).

The produced gas consists of several combustible and non-combustible fractions; depending on both the type of biomass and the operational conditions of the process. In general, the produced gas has a calorific value of between 4.5 and $6 \mathrm{MJ} / \mathrm{m}^{3}$, corresponding to 10 to $50 \%$ of the calorific value of natural gas (Akia et al., 2014).

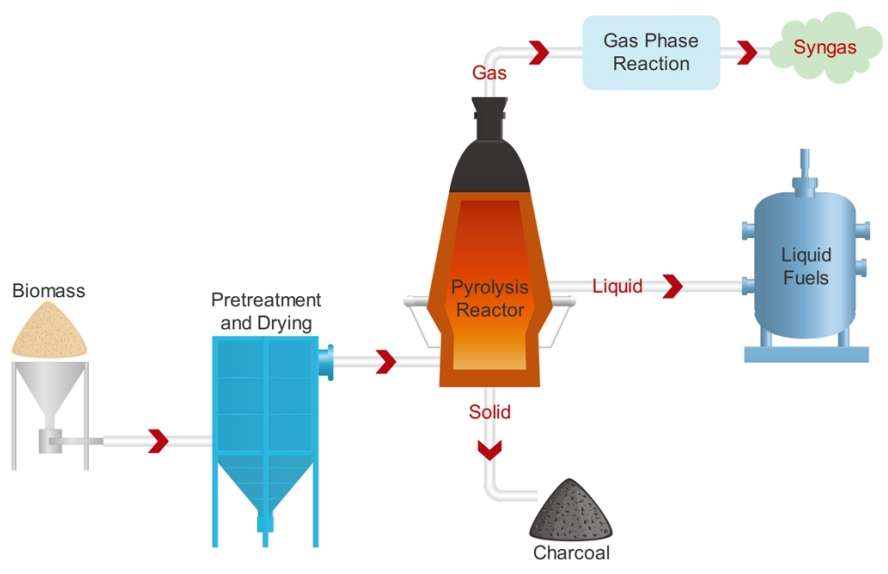

Fig. 14. Biomass gasification scheme.

The biomass gasification process essentially involves four different processes (Portha et al., 2017) (Fig. 14):

\section{Oxidation (exothermic stage)}

The oxidation phase of biomass gasification is performed to reach the necessary operating temperature to implement the endothermic processes. Oxidation is carried out in the absence of oxygen (Molino et al., 2016).

The reactions occurring during the oxidation phase are as follows (Eqs. 3, 4, and 5) (Kaltschmitt, 2013):

$$
\begin{array}{llll}
\text { Combustion of coal } & \mathrm{C}+\mathrm{O}_{2} \rightarrow \mathrm{CO}_{2} & \Delta \mathrm{H}=-394 \mathrm{~kJ} / \mathrm{mol} & \text { Eq. } 3 \\
\text { Partial oxidation } & \mathrm{C}+1 / 2 \mathrm{O}_{2} \rightarrow \mathrm{CO} & \Delta \mathrm{H}=-111 \mathrm{~kJ} / \mathrm{mol} & \text { Eq. } 4 \\
\text { Hydrogen combustion } & \mathrm{H}_{2}+1 / 2 \mathrm{O}_{2} \rightarrow \mathrm{H}_{2} \mathrm{O} & \Delta \mathrm{H}=-242 \mathrm{~kJ} / \mathrm{mol} & \text { Eq. } 5
\end{array}
$$

Therefore, the main purpose of this step is to obtain the thermal energy that allows the entire process to be performed. The resulting combustion product is a mix of $\mathrm{CO}, \mathrm{CO}_{2}$, and water.

\section{Drying (endothermic stage)}

In the drying step, the moisture in the biomass is removed at over $100^{\circ} \mathrm{C}$ by converting it into steam followed by elevating the temperature to $150{ }^{\circ} \mathrm{C}$ to complete the process. The heat input necessary for this phase is proportional to the moisture content of the raw material and generally derives from the previous oxidation phase (Molino et al., 2016).

\section{Pyrolysis (endothermic stage)}

Pyrolysis is the anaerobic thermal decomposition of the carbonaceous material deriving from the biomass, which generates a solid fraction (represented by a fraction of high carbon content, called "char" and by inert residues in the form of ash), a liquid fraction (called "tars" that consists of complex and condensable organic substances at relatively low temperatures), and a gaseous fraction (a mixture of incondensable gases such as $\mathrm{H}_{2}, \mathrm{CO}_{2}$, and $\mathrm{CO}$ and light hydrocarbons at room temperature, called pyrolysis gas) (Roos,
2010). In this step, the breakage of the chemical bonds of the molecules (with higher molecular weights), leads to the formation of lighter molecules. The pyrolysis stage is endothermic and takes place at temperatures ranging between 250 and $700{ }^{\circ} \mathrm{C}(\mathrm{Eq} \cdot 6)$ :

Biomass $\leftrightarrow \mathrm{H}_{2}+\mathrm{CO}+\mathrm{CO}_{2}+\mathrm{CH}_{4}+\mathrm{H}_{2} \mathrm{O}(\mathrm{g})+\mathrm{Tar}+\mathrm{Char}$

Eq. 6

In Equation 6, since biomass is already treated, the term biomass can be replaced by the formula of cellulose $\mathrm{C}_{6} \mathrm{H}_{10} \mathrm{O}_{6}$, which is the main component of the biomass contributing around 50-55\% of the total weight of the matrix (Molino et al., 2016). Regarding cellulose, pyrolysis reactions occur between 600 and $700{ }^{\circ} \mathrm{C}$.

Within this process step, on average $12.01 \mathrm{~kg}$ of carbon is completely oxidized with $22.39 \mathrm{~m}^{3}$ of oxygen supplied by the air to produce $22.26 \mathrm{~m}^{3}$ of CO and about $0.04 \mathrm{GJ}$ of heat (Molino et al., 2016).

\section{Reduction (endothermic stage)}

In the reduction phase (gas phase reactions), the mixture of gas and coal, derived from the previous phases of pyrolysis and oxidation, are transformed. The products of the previous phases react with each other, leading to the formation of the final syngas. The main reactions occurring in the reduction phase are shown in Equations 7, 8, 9, and 10) (Zhang et al., 2013):

Boudouard reaction:

$\mathrm{C}+\mathrm{CO}_{2} \leftrightarrow 2 \mathrm{CO}$

$\Delta \mathrm{H}=172 \mathrm{~kJ} / \mathrm{mole}$

Character reform:

$\mathrm{C}+\mathrm{H}_{2} \mathrm{O} \leftrightarrow \mathrm{CO}+\mathrm{H}_{2} \quad \Delta \mathrm{H}=131 \mathrm{~kJ} / \mathrm{mole}$

Water gas displacement reaction:

$\mathrm{CO}+\mathrm{H}_{2} \mathrm{O} \leftrightarrow \mathrm{CO}_{2}+\mathrm{H}_{2} \quad \Delta \mathrm{H}=-41 \mathrm{~kJ} /$ mole

Methanation:

$\mathrm{C}+2 \mathrm{H}_{2} \leftrightarrow \mathrm{CH}_{4}$

$\Delta \mathrm{H}=-75 \mathrm{~kJ} / \mathrm{mole}$

Equations 7 and 8 are endothermic and are favoured by increases in temperature, while Equations $\mathbf{9}$ and $\mathbf{1 0}$ are exothermic and are positively fostered by low temperatures; ultimately the global endothermic contribution is greater than the exothermic one, making the contribution of the reactions globally endothermic, so that the whole step requires energy.

The reduction temperature represents a fundamental parameter in determining the composition and characteristics (such as tar pre-stress and lower heating capacity) of the syngas and of the final solid residue. In fact, the higher the temperature of the process is, the higher the degree of oxidation of the coal will be; resulting in low levels of solid residues and tar at the end of the process.

The gasification processes are carried out at temperatures ranging between 800 and $1100{ }^{\circ} \mathrm{C}$, while this range could be between 500 and 1600 ${ }^{\circ} \mathrm{C}$, when the process requires the use of oxygen for the gasification phase (Shen et al., 2012).

In conclusion, gasification technology can be a proper solution for the production of energy from biomass, despite the high concentrations of pollutants potentially generated by the process as by-products (i.e., tar, ammonia, hydrogen sulphide, and hydrochloric acid).

\subsubsection{Liquefaction}

Liquefaction is a biomass conversion process conducted in water at moderate temperatures ranging between 280 to $370{ }^{\circ} \mathrm{C}$ and high pressures (10-25 MPa). A liquid biogranulate, similar to crude oil, as well as other gaseous, aqueous, and solid by-products are also generated (López Barreiro et al., 2013). 
The obtained products has a high heating and a low oxygen content making it a chemically stable fuel. The main purpose of liquefaction is to obtain high $\mathrm{H} / \mathrm{C}$ ratio oil. For this type of conversion, two processes, based on the raw materials used, are distinguished: lignocellulosic biomass (dry raw material) liquefaction and algal biomass (wet raw material) liquefaction. In both cases, the raw material requires a preliminary treatment, which consists in the removal of woody biomass contaminants along with obtaining a stable suspension, thereby reducing the size of the particles (through alkaline treatments) for easy pumping into reactors (Gollakota et al., 2018).

Principally, the most used process includes the use of lignocellulosic biomass processed at a temperature of about $350{ }^{\circ} \mathrm{C}$ and a pressure of $150 \mathrm{bar}$ for about $15 \mathrm{~min}$. Under these process conditions, a spontaneous phase separation takes place, generating a gaseous phase of $\mathrm{CO}_{2}$, solid residues, biocrude, and a minor aqueous phase (Rowbotham et al., 2012). The obtained solid phase material could be used directly as biofuel or fertilizer (Fig. 15). The aqueous phase could be used inside the plant for processes requiring water or in anaerobic digestion. The bio-crude produced, which has a low oxygen content, requires further refining to be commercially exploited ( $\mathrm{Yu}$ et al., 2011).

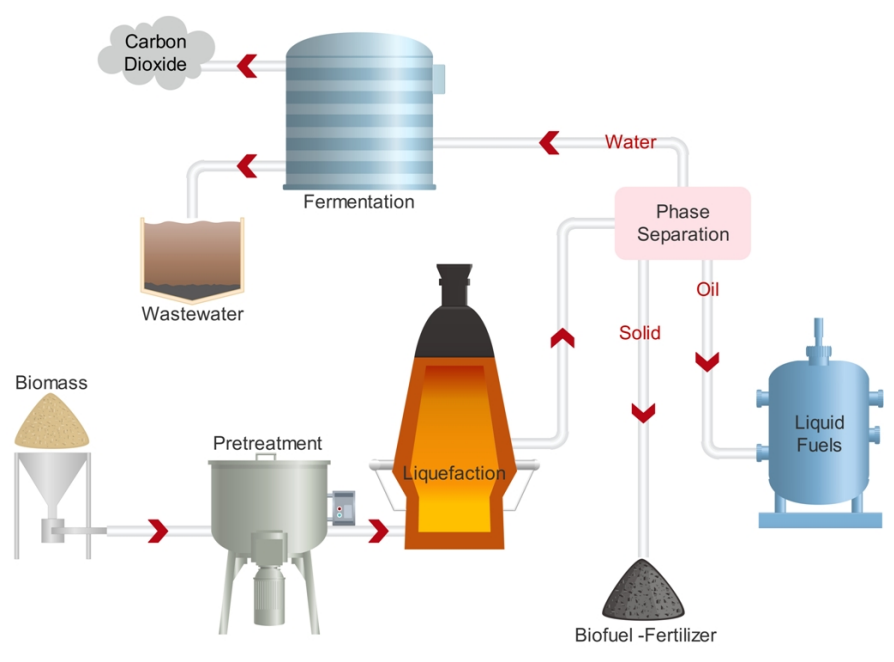

Fig. 15. Biomass liquefaction scheme.

\subsection{Biochemical conversion of biomass}

Biochemical conversion processes allow the decomposition of biomass to available carbohydrates, which could be converted into liquid fuels and biogas, as well as different types of bio-products, using biological agents such as bacteria, enzymes, etc. (Mahalaxmi and Williford, 2014). The most used biochemical technologies include anaerobic digestion and fermentation (Brethauer and Studer, 2015).

\subsubsection{Anaerobic digestion}

Anaerobic digestion is a multi-step biological process that is useful not only for proper waste management but also for generating renewable energy (Zamani, 2015). It consists of four basic stages, i.e., hydrolysis, acidogenesis, acetogenesis, and methanogenesis. During the whole process, there are series of chemical reactions occuring through natural metabolic pathways, enabled by microorganisms in an oxygen-free environment. These reactions break down the organic macromolecules into simpler molecules leading to the generation of biogas (a mix of methane and carbon dioxide as well as traces of other gases) and digestate. The feedstocks commonly used in this type of process, include sewage sludge, agricultural residues, MSW, and animal manure (Sharma, 2015). A schematic presentation of anaerobic digestion process is shown in Figure 16.

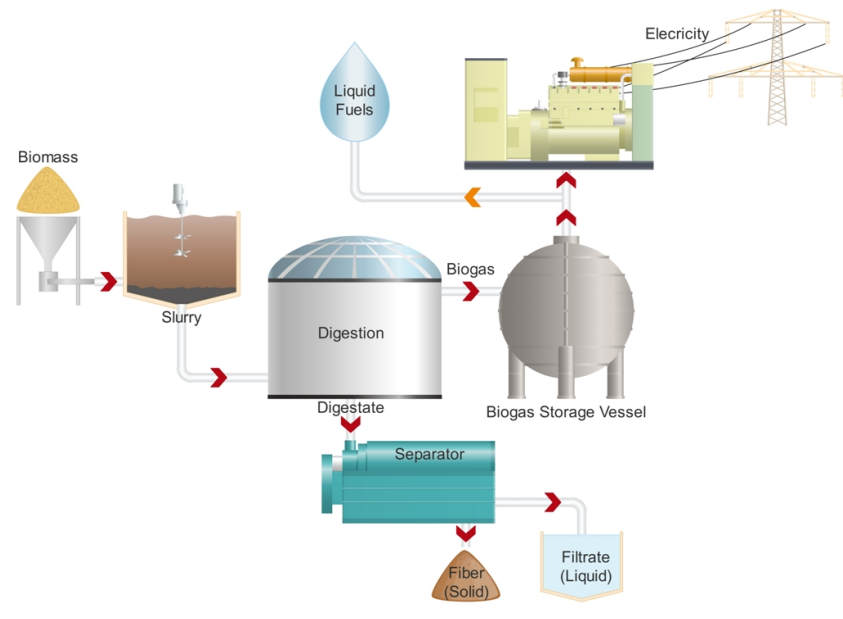

Fig. 16. Biomass anaerobic digestion scheme.

The biogas produced possesses an energy content $20-40 \%$ lower than the heating value of the raw material. The process is ideal for organic wastes with a moisture content ranging between 80 to $90 \%$. One of the advantages of the process lies in the potential of the final biogas to be used directly in ignition gas engines and gas turbines. The overall conversion efficiency of this process is $21 \%$. Residual heat from the engines and turbines can be recovered through an exchanger (Yadvika et al., 2004).

The basic stages of the anaerobic digestion process are explained below (Zamani, 2015):

\section{Hydrolysis}

Hydrolysis represents the initial phase of the process: biomass (consisting of very large organic polymers such as fats, carbohydrates, and proteins) is converted into smaller molecules such as fatty acids, simple sugars, and amino acids, respectively (Horan, 2018). It should be noted that most of the large molecules are further decomposed in the acidogenesis stage. On the other hand, other by-products resulting from the hydrolysis stage, including hydrogen and acetate, are used in the final stage of the process, i.e., methanogenesis.

\section{Acidogenesis}

Acidogenesis is the second stage of anaerobic digestion, through which acidogenic microorganisms (fermentative bacteria) further decompose the products of the hydrolysis stage, producing $\mathrm{NH}_{3}, \mathrm{CO}_{2}, \mathrm{H}_{2}, \mathrm{H}_{2} \mathrm{~S}$, alcohols, lighter volatile fatty acids, carbonic acids, and alcohols. Acidogenesis process only partially decomposes the biomass; therefore, for the final production of methane, the acetogenesis process is required.

\section{Acetogenesis}

This step employs acetogenic microorganisms catabolising the products created in the acidogenesis phase into acetic acid $\left(\mathrm{CH}_{3} \mathrm{COOH}\right), \mathrm{CO}_{2}$, and $\mathrm{H}_{2}$. Acetogens finalize the break down process of the biomass facilitating the action of the methanogenic archaea to produce methane as biofuel.

\section{Methanogenesis}

Methanogenesis is the final stage of anaerobic digestion during which, as mentioned earlier, methane is generated from the main products of acetogenesis (i.e., $\mathrm{CH}_{3} \mathrm{COOH}$ and $\mathrm{CO}_{2}$ ) through hydrogenotrophic methanogenesis and/or acetoclastic methanogenesis as shown in Equations 11 and 12 , respectively. 
$\begin{array}{lll}\text { Hydrogenotrophic methanogenesis } & \mathrm{CO}_{2}+4 \mathrm{H}_{2} \rightarrow \mathrm{CH}_{4}+2 \mathrm{H}_{2} \mathrm{O} & \text { Eq. } 11 \\ \text { Acetoclastic methanogenesis } & \mathrm{CH}_{3} \mathrm{COOH} \rightarrow \mathrm{CH}_{4}+\mathrm{CO}_{2} & \text { Eq. } 12\end{array}$

\subsubsection{Fermentation}

The fermentation process of organic materials consists of a series of biochemical reactions, converting simple sugars (hexoses and pentoses) into ethanol and $\mathrm{CO}_{2}$, under anaerobic conditions by microorganisms mainly yeasts (Eq. 13). The microorganisms commonly used to carry out the process are the Saccharomyces Cerevisiae, while the feedstock used for this type of process are categorized into three different classes: sugars, starch, and lignocellulosic substrates. In detail, the theoretical yield of the process is $51.14 \mathrm{~g}$ of ethanol and $48.86 \mathrm{~g}$ of $\mathrm{CO}_{2}$, from $100 \mathrm{~g}$ of hexoses or pentoses (Eqs. 14 and 15). In addition to ethanol and $\mathrm{CO}_{2}$, glycerol and carboxylic acids are also produced as by-products. The quality and yields of the process depend on various factors such as feedstock, temperature, $\mathrm{pH}$, inoculum, and fermentation time (Strezov et al., 2014).

Sugars $\rightarrow$ Ethanol $+\mathrm{CO}_{2}+$ by-products

Eq. 13

$\mathrm{C}_{6} \mathrm{H}_{12} \mathrm{O}_{6}$ (hexoses) $\rightarrow 2 \mathrm{C}_{2} \mathrm{H}_{5} \mathrm{OH}+2 \mathrm{CO}_{2}$

Eq. 14

$3 \mathrm{C}_{5} \mathrm{H}_{10} \mathrm{O}_{5}$ (pentoses) $\rightarrow 5 \mathrm{C}_{2} \mathrm{H}_{5} \mathrm{OH}+5 \mathrm{CO}_{2}$

Eq. 15

The conversion of sugars into ethanol could take place through different metabolic pathways depending on the starting substrate. More specifically, (a) from hexoses such as glucose, through glycolysis or Embden-Meyerhof pathway (EMP) (Taherzadeh and Karimi, 2008) and (b) from pentoses, through a pentose phosphate pathway (PPP). The conversion reactions of the hexoses are faster than those of the pentoses.

At the end of the conversion process, ethanol is distilled and dehydrated, in order to obtain concentrated alcohol, while the solid residues can be used as fuel in boilers for the production of gas or can be used as feed for livestock (Mariod, 2016). A schematic presentation of biomass fermentation process is shown in Figure 17.

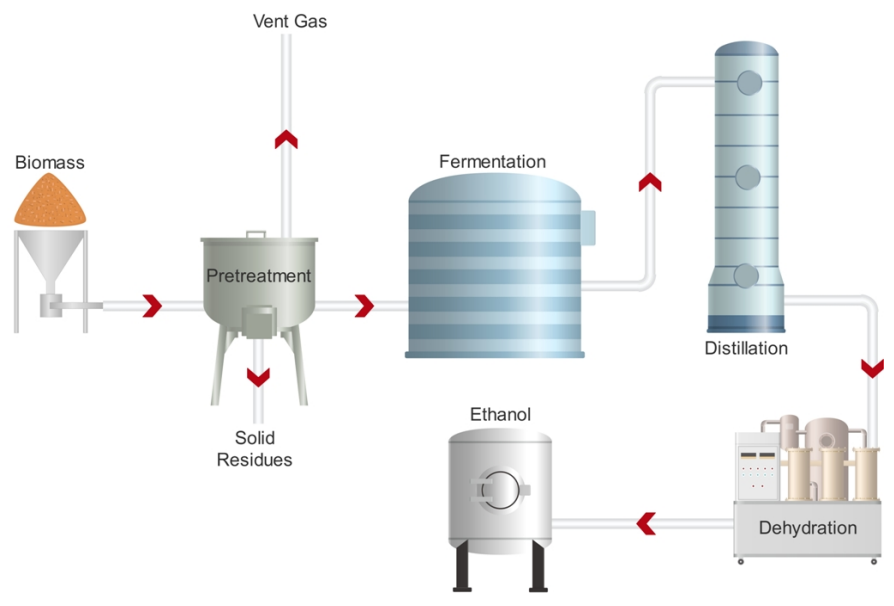

Fig. 17. Biomass fermentation scheme.

\subsection{Physico-chemical conversion of biomass}

The physico-chemical conversion processes of biomass leads to the production of high-density biofuels (Fig. 18). More specifically, various types of vegetable oil ad animal fats are converted into biodiesel through esterification and/or transesterification processes. Major vegetable oils used to produce first generation biodiesel include rapeseed oil and sunflower oil accounting for $80-85 \%$ and $10-15 \%$ of the total biodiesel production worldwide, respectively (Fukuda et al., 2001). Waste oils including waste cooking oil (WCO) and microbial oil including algal oil could also be used to produce second and third generation biofiesel, respectively.

It should be noted that oils are mainly composed of triglycerides, which do not represent a usable fuel. In fact, the transformation of the crude vegetable oil is necessary as otherwise, problems such as incomplete combustion and consequent accumulation of residues in engines are expected. Therefore, the raw material must undergo further processing, i.e., mainly transesterification, to break apart the triglyceride molecules into their constituents, i.e., fatty acids and glycerol. The latter is in fact the source of high viscosity of vegetable oils.

Through the transesterification reaction, the triglycerides are converted into methyl or ethyl esters (biodiesel) through the use of methyl or ethyl alcohol (in excess), respectively, in the presence of mostly an alkaline catalyst (i.e., $\mathrm{NaOH}$ or $\mathrm{KOH})(\mathrm{Eq} .16)$ :

Oil + Short chain alcohol $\rightarrow$ Biodiesel + glycerol

Eq. 16

The transesterification process of triglycerides occurs at low temperatures $\left(50-70{ }^{\circ} \mathrm{C}\right)$ and at atmospheric pressure. The obtained product is neutralized and purified, especially for the presence of glycerol (Leung et al., 2010).

The glycerol fraction is much denser than the biodiesel fraction, so it can be separated from biodiesel using a phase separator. Once the glycerol and biodiesel phases have been separated, the excess alcohol could be removed by distillation or partial evaporation. Once separated from glycerol, biodiesel is usually purified by water-washing (liquid-liquid extraction) in order to remove residual catalysts and soaps. The product is finally dried and stored.

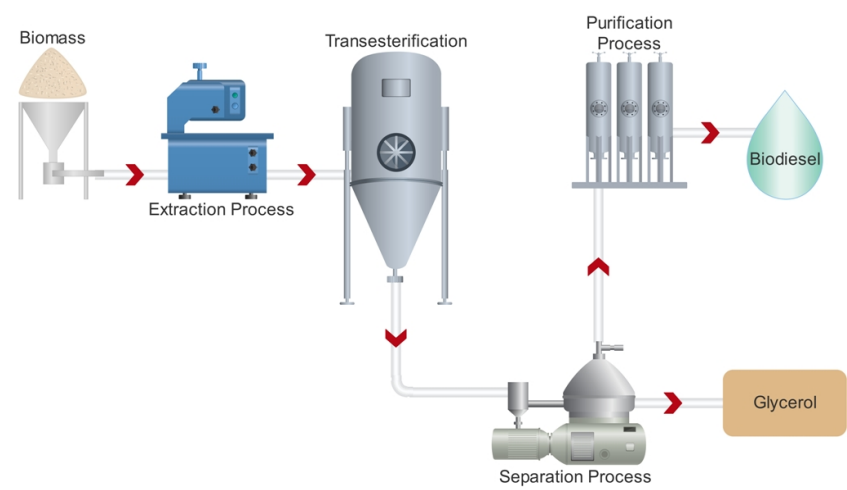

Fig. 18. Biomass physico-chemical conversion scheme.

Biodiesel is a renewable, biodegradable, and non-toxic fuel and its physicochemical parameters are very close to those of diesel. Some unique features, such as high oxygen content and high lubrication properties, ensure efficient combustion of biodiesel in diesel engines.

Regarding the glycerol (or glycerine), rather than considering it as waste, it could be valorized into various value-added compounds with applications in various industries such food and pharmaceutical ones (Canakci and Van Gerpen, 1999).

\section{Biomass vs. other renewable energies}

According to the latest estimates provided by the International Energy Agency (IEA, 2018), global energy consumption has grown by $37 \%$ over the last 15 years, standing at 368 EJ in 2016 against 269 EJ in 2000. Currently, renewable energy resources account for $66 \mathrm{EJ}$, accounting for approximately $18 \%$ of the total global energy consumption out of which $72.3 \%$ is contributed by biomass (WBA, 2018) (Fig. 19). 


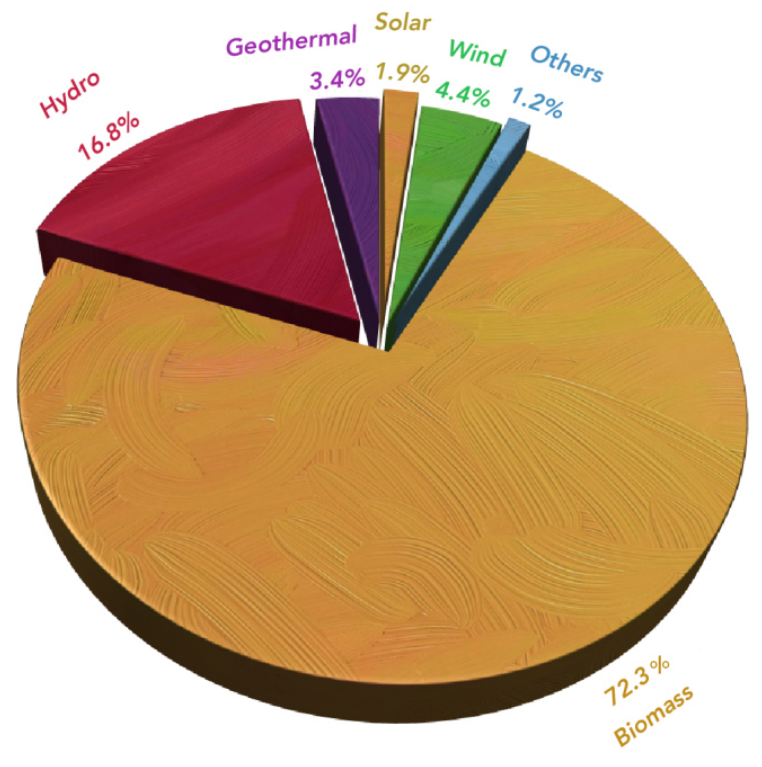

Fig. 19. Global renewable energy resources.

Biomass-derived energy production has increased from $42.8 \mathrm{EJ}$ in 2000 to $56.5 \mathrm{EJ}$ in $2016(+32 \%)$, largely matching the increase in demand over the last two decades (WBA, 2018) (Table 7). As shown, in 2016, biomass-derived energy production is mainly contributed by solid biomass and liquid biofuel, collectively contributing $93 \%$ of the whole value. Moreover, according to the production trend across 2000-2016, liquid biofuel showed an outstanding growth in utilization, accounting for 6\% of the total bioenergy supply in 2016, compared to $1 \%$ in 2000 .

Table 7.

Bioenergy supply of biomass in 2000-2016 (WBA, 2018).

\begin{tabular}{lcccccc}
\hline \multirow{2}{*}{ Year } & \multicolumn{6}{c}{ Bioenergy supply through biomass (EJ) } \\
\cline { 2 - 7 } & Total & $\begin{array}{c}\text { Municipal solid } \\
\text { waste }\end{array}$ & $\begin{array}{c}\text { Industrial } \\
\text { waste }\end{array}$ & $\begin{array}{c}\text { Solid } \\
\text { biomass }\end{array}$ & Biogas & $\begin{array}{c}\text { Liquid } \\
\text { biofuels }\end{array}$ \\
\hline 2000 & 42.8 & 0.74 & 0.47 & 40.9 & 0.28 & 0.42 \\
2016 & 56.5 & 1.43 & 1.03 & 49.1 & 1.31 & 3.59 \\
\hline
\end{tabular}

Taking into consideration the end-products derived from biomass, in all cases, an enormous increase in global production has recorded over the last 15 years (Table 8), confirming a trend towards a renewable approach to production and consumption. Specifically and as mentioned earlier, global biofuels production has registered a growth trend from approximately 16 billion $\mathrm{L}$ in the year 2000 to 143 billion $\mathrm{L}$ in the year 2016 (of which $65 \%$ was bioethanol, $25 \%$ was biodiesel, and $10 \%$ was other biofuels). In addition, electricity, heat, and biogas have recorded outstanding growths in production (WBA, 2018).

Furthermore, the renewable energy sector has recorded a growing trend in recruitment with the latest estimates showing that employment by this sector has risen from 2.4 million in 2012 to 3.1 million in 2017. This further highlights the important role of the biomass sector in driving and boosting the world economy (WBA, 2018).

\subsection{Economic and environmental analysis of biomass-derived energy production}

Among the various resources and renewable technologies, biomass could represent the most promising economic lever for developing countries,
Table 8.

Global production of the main energy products derived from biomass in 2000 and 2016 (WBA, 2018).

\begin{tabular}{lccc}
\hline End product & Year & Global production & Unit \\
\hline Electricity & 2000 & 164 & Terawatt h (TWh) \\
& 2015 & 528 & \\
Heat & 2000 & 414,081 & Terajoule (TJ) \\
& 2015 & 940,492 & \\
Liquid biofuels & 2000 & 15.9 & Billion L \\
& 2017 & 143 & $\mathrm{~m}^{3}$ \\
\hline Biogas & 2000 & 13.2 & 60.8 \\
\hline
\end{tabular}

providing benefits to the level of employment and, at the same time, environmental protection.

In order to provide an economic analysis of the different production technologies generating the main products from biomass (i.e., electricity and biofuels), an assessment of the production cost, conversion efficiency, and size of the processing is presented. The parameters taken into consideration include the levelized cost of energy (LCOE, USD/kWh) and the cost of the final biofuel (USD/L), for the production of electrical energy and biofuels, respectively. Table 9 shows the comparison between the most commonly used technologies and the related evaluation parameters.

As presented, manufacturing cost and conversion efficiency of the processes taken into consideration can vary significantly, based on the raw material used and the type of conversion performed. In general, the cost of electricity production is between $0.03 \mathrm{USD}$ and $0.24 \mathrm{USD} / \mathrm{kWh}$, while for the biofuel, the production cost ranges between 0.13 and $0.99 \mathrm{USD} / \mathrm{L}$. Nevertheless, the prices of conventional electricity and fuels are still competitive compared to their bio-based counterparts. Despite this, unlike the use of fossil fuels, the environmental advantages are huge for several reasons:

I. Biomass is a renewable energy source and therefore, it will not exhaust;

II. Biomass energy is generated mainly from constantly increasing wastes disposed of by various sectors, which would otherwise be released into the environment;

III. The use of biomass could significantly reduce the amount of GHG emissions, contributing to the mitigation of environmental crises such as climate change and global warming.

Regarding the last item, several studies have shown a clear decrease in GHGs emissions, in specific cases even greater than $90 \%$ in response to the replacement of fossil fuels with biomass-derived energy. Figure 20 shows a comparison of $\mathrm{CO}_{2}$ emissions (expressed as $\mathrm{Mt} \mathrm{CO}_{2}$-eq/Mtoe) of conventional energy sources and biomass-derived energy sources, with their respective savings in GHGs emissions.

\section{Concluding remarks and future prospects}

Replacement of fossil energy carriers with biomass-derived energy carriers could bring about positive impacts from multiple perspectives, i.e., economic, environmental, and health. Moreover, production of biomassderived energy could be achieved under any geographical conditions owing the large availability of biomass all over the world while it could simultaneously contribute to efficient management of various waste streams. Technological innovations to increase productivity and reduce costs are the main challenges to further expand the share of such renewable energy carriers. Efforts should be directed toward the development of more user-friendly cost-efficient technologies at various scales to attract more investment in the field.

Creating further awareness towards the advantages of biomass exploitation for renewable energy production is also necessary. It should be 
Table 9.

Economic evaluation of several biomass technologies for electricity and biofuels production (De Wit et al., 2010; Dutta et al., 2011; Chen et al., 2012; IRENA, 2012).

\begin{tabular}{lccc}
\hline & \multicolumn{2}{c}{ Electricity } & \\
\hline Technology & Plant size (dry ton/yr) & LCOE* (USD/kWh) & Conversion efficiency (kWh/ton) \\
\hline Gasification & 175,000 & $0.06-0.24$ & $30-40 \%$ \\
Anaerobic digestion & 770,000 & $0.06-0.19$ & $25-40 \%$ \\
Combustion & 350,000 & $0.03-0.22$ & $25-35 \%$ \\
Pyrolysis & 175,000 & $0.07-0.24$ & $33-50 \%$ \\
\hline & Biofuels & Conversion efficiency \\
\hline Technology & Plant size (million L/yr) & USD/L & (L of ethanol or biodiesel/ton) \\
\hline Enzymatic hydrolysis & 231 & $0.37-0.66$ & $29-33 \%$ \\
Thermochemical process & 245 & $0.35-0.88$ & $24-32 \%$ \\
Gasification & $111-143$ & $0.46-0.47$ & $18-23 \%$ \\
Fast pyrolysis & $134-220$ & $0.13-0.16$ & $20-33 \%$ \\
Fisher-Tropsch & $45-360$ & $0.35-0.94$ & $14 \%$ \\
Transesterification & $30-284$ & $0.68-0.99$ & $97-99 \%$ \\
\hline
\end{tabular}

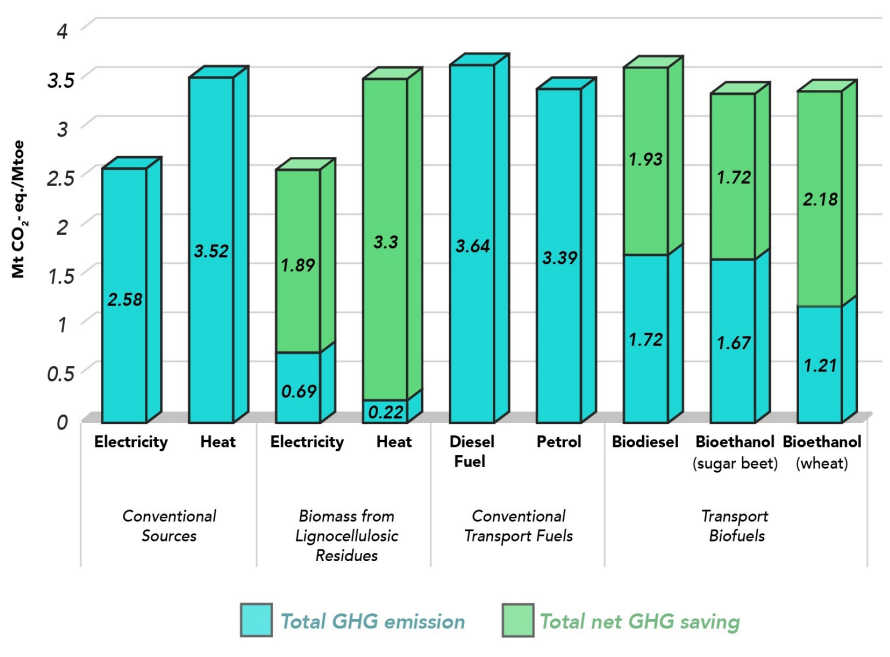

Fig. 20. Comparison of $\mathrm{CO}_{2}$ emissions from conventional energy sources biomass-derived energy sources along with their respective savings in GHGs emissions

highlighted that production of biomass-derived energy carriers, i.e., bioelectricity and biofuels could be regarded as an efficient means of meeting some of the main Sustainable Development Goals (SDGs) set by the United Nations General Assembly in 2015 for the year 2030 in particular Affordable and Clean Energy.

\section{References}

[1] Abejón, R., Pérez-Acebo, H., Clavijo, L., 2018. Alternatives for chemical and biochemical lignin valorization: hot topics from a bibliometric analysis of the research published during the 2000-2016 period. Processes. 6(8), 98
[2] Agbor, V.B., Cicek, N., Sparling, R., Berlin, A., Levin, D.B., 2011 Biomass pretreatment: fundamentals toward application. Biotechnol. Adv. 29(6), 675-685.

[3] Akia, M., Yazdani, F., Motaee, E., Han, D., Arandiyan, H., 2014. A review on conversion of biomass to biofuel by nanocatalysts. Biofuel Res. J. 1(1), 16-25.

[4] Alaswada, A., Dassisti, M., Prescotta, T., Olabia, A.G., 2015 Technologies and developments of third generation biofuel production. Renew. Sust. Energy Rev. 51, 1446-1460.

[5] Amidon, T.E., Wood, C.D., Shupe, A.M., Wang, Y., Graves, M. Liu, S., 2008. Biorefinery: conversion of woody biomass to chemicals, energy and materials. J. Biobased Mater. Bioenergy. 2(2), 100-120.

[6] Anex, R.P., Aden, A., Kazi, F.K., Fortman, J., Swanson, R.M., Wright, M., Satrio, J.A., Brown, R.C., Daugaard, D.E., Platon, A., Kothandaraman, G., Hsu, D.D., Dutta, A., 2010. Techno economic comparison of biomass-to-transportation fuels via pyrolysis, gasification, and biochemical pathways. Fuel. 89, 529-535.

[7] Arias, F.E.A., Beneduci, A., Chidichimo, F., Furia, E., Straface, S., 2017. Study of the adsorption of mercury (II) on lignocellulosic materials under static and dynamic conditions. Chemosphere. 180, 11-23.

[8] Bajpai, P., 2009. Xylanases, in: Schaechter, M., Lederberg, J. (Eds.), Encyclopedia of Microbiology. Academic Press, San Diego, pp. 600-612.

[9] Bala, J.D., Lalung, J., Al-Gheethi, A.A.S., Norli, I., 2016. A Review on Biofuel and Bioresources for Environmental Applications, in: Ahmad, M., Ismail, M., Riffat, S. (Eds.) Renewable Energy and Sustainable Technologies for Building and Environmental Applications. Springer, Cham, pp. 205-225

[10] Biochemical Conversion: Using Hydrolysis, Fermentation, and Catalysis to Make Fuels and Chemicals.

[11] Bonechi, C., Consumi, M., Donati, A., Leone, G., Magnani, A., Tamasi, G., Rossi, C., 2017. Biomass: An overview, in: Dalena, F., Basile, A., Rossi, C. (Eds.), Bioenergy Systems for the Future: Prospects for Biofuels and Biohydrogen. Elsevier Publishing, London, pp. 3-42.

[12] Brethauer, S., Studer, M.H., 2015. Biochemical conversion processes of lignocellulosic biomass to fuels and chemicals-a review. Chimia. 69(10), 572-581. 
[13] Buléon, A., Colonna, P., Planchot, V., Ball, S., 1998. Starch granules: structure and biosynthesis. Int. J. Biol. Macromol. 23(2), 85-112.

[14] Canakci, M., Van Gerpen, J.H., 1999. Biodiesel production via acid catalysis. Transactions of the ASAE. 42(5), 1203-1210.

[15] Carpenter, D., Westover, T.L., Czernik, S., Jablonski, W., 2014. Biomass feedstocks for renewable fuel production: a review of the impacts of feedstock and pretreatment on the yield and product distribution of fast pyrolysis bio-oils and vapors. Green Chem. 16(2), 384-406

[16] Chen, H., 2014. Chemical composition and structure of natural lignocellulose, in: Chen, H. (Ed.), Biotechnology of Lignocellulose. Springer, Dordrecht, pp. 25-71.

[17] Chen, J., Li, C., Ristovski, Z., Milic, A., Gu, Y., Islam, M.S., Wang, S., Hao, J., Zhang, H., He, C., Guo, H., Fu, H., Miljevic, B., Morawsk, L., Thai, P., 2017. A review of biomass burning: Emissions and impacts on air quality, health and climate in China. Sci. Total Environ. 579, 1000-1034.

[18] Chen, X., Khanna, M., Yeh, S., 2012. Stimulating learning-by-doing in advanced biofuels: effectiveness of alternative policies. Environ. Res. Lett. 7(4), 045907.

[19] Chum, H., Faaij, A., Moreira, J., Berndes, G., Dhamija, P., Dong, H., Gabrielle, B., Goss Eng, A., Lucht, W., Mapako, M., Masera Cerutti, O., McIntyre, T., Minowa, T., Pingoud, K., 2011. Bioenergy, in: Edenhofer, O., Pichs-Madruga, R., Sokona, Y., Seyboth, K., Matschoss, P., Kadner, S., Zwickel, T., Eickemeier, P., Hansen, G., Schlömer, S., von Stechow, C. (Eds.), IPCC Special Report on Renewable Energy Sources and Climate Change Mitigation. Cambridge University Press, Cambridge

[20] Dalena, F., Senatore, A., Tursi, A., Basile, A., 2017. Bioenergy production from second- and third-generation feedstocks, in: Dalena, F., Basile, A., Rossi, C. (Eds.). Bioenergy Systems for the Future: Prospects for Biofuels and Biohydrogen. Elsevier Publishing, London, pp. 559-599.

[21] Damartzis, T., Zabaniotou, A., 2011. Thermochemical conversion of biomass to second generation biofuels through integrated process design-a review. Renew. Sust. Energy Rev. 15(1), 366-378.

[22] Demirbas, A., 2010. Use of algae as biofuel sources. Energy Convers. Manage. 51(12), 2738-2749

[23] de Wit, M., Junginger, M., Lensink, S., Londo, M., Faaij, A., 2010. Competition between biofuels: modelling technological learning and cost reductions over time. Biomass Bioenergy. 34(2), 203-217.

[24] Di benedetto, A., 2011. The potential of aquatic biomass for $\mathrm{CO}_{2-}$ enhanced fixation and energy production. Greenhouse Gases Sci. Technol. 1(1), 58-71.

[25] Di Blasi, C., 2008. Modeling chemical and physical processes of wood and biomass pyrolysis. Prog. Energy Combust. Sci. 34(1), 47-90.

[26] Edwards, S., Chaplin, M.F., Blackwood, A.D., Dettmar, P.W., 2003. Primary structure of arabinoxylans of ispaghula husk and wheat bran. Proc. Nutr. Soc. 62(1), 217-222.

[27] Fromm, J., Rockel, B., Lautner, S., Windeisen, E., Wanner, G., 2003. Lignin distribution in wood cell walls determined by TEM and backscattered SEM techniques. J. Struct. Biol. 143(1), 77-84.

[28] Fukuda, H., Kondo, A., Noda, H., 2001. Biodiesel fuel production by transesterification of oils. J. Biosci. Bioeng. 92(5), 405-416.

[29] García, V., Päkkilä, J., Ojamo, H., Muurinen, E., Keiski, R.L., 2011. Challenges in biobutanol production: how to improve the efficiency? Renew. Sust. Energy Rev. 15(2), 964-980.

[30] Gollakota, A.R.K., Kishore, N., Gu, S., 2018. A review on hydrothermal liquefaction of biomass. Renew. Sust. Energy Rev. 81, $1378-1392$

[31] Habert, G., Bouzidi, Y., Chen, C., Jullien, A., 2010. Development of a depletion indicator for natural resources used in concrete. Resour. Conserv. Recycl. 54(6), 364-376.

[32] Harmsen, P.F.H., Hujigen, W., Bermudez, L., Bakker, R., 2010. Literature review of physical and chemical pretreatment processes for lignocellulosic biomass. Wageningen UR Food \& Biobased Research.

[33] Hodásová, L., Jablonský, M., Škulcová, A., Ház, A., 2015. Lignin, potential products and their market value. Wood Res. 60(6), 973-986.
[34] Horan, N.J., 2018. Introduction, in: Horan, N., Yaser, A., Wid, N. (Eds.), Anaerobic Digestion Processes. Green Energy and Technology. Springer, Singapore, pp 1-7.

[35] Huber, G.W., Iborra, S., Corma, A., 2006. Synthesis of transportation fuels from biomass: chemistry, catalysts, and engineering. Chem. Rev. 106(9), 4044-4098.

[36] IEA, 2018. World energy balances, IEA World Energy Statistics and Balances (database). Int. Energy Agency.

[37] Imai, M., Ikari, K., Suzuki, I., 2004. High-performance hydrolysis of cellulose using mixed cellulase species and ultrasonication pretreatment. Biochem. Eng. J. 17(2), 79-83.

[38] IRENA, 2012. Biomass for power generation, renewable energy technologies: Cost Analysis Series, Irena Working Paper, International Renewable Energy Agency.

[39] Jacobsson, S., Johnson, A., 2000. The diffusion of renewable energy technology: an analytical framework and key issues for research. Energy Policy. 28(9), 625-640.

[40] Jiang, T.D., 2001. Lignin, Chemical Ind. Press, Beijing, pp. 1-17.

[41] Jindal, M.K., Jha, M.K., 2016. Hydrothermal liquefaction of wood: a critical review. Rev. Chem. Eng. 32(4), 459-488.

[42] Kaltschmitt, M., 2013. Renewable energy from biomass, Introduction, in: Kaltschmitt, M., Themelis, N.J., Bronicki, L.Y., Söder, L., Vega, L.A. (Eds.), Renewable Energy Systems. Springer, New York

[43] Kaushika, N.D., Reddy, K.S., Kaushik, K., 2016. Biomass Energy and Power Systems, in: Kaushika, N.D., Reddy, K.S., Kaushik, K. (Eds.). Sustainable Energy and the Environment: A Clean Technology Approach. Springer, Cham, pp. 123-137.

[44] Kosa, M., Ragauskas, A.J., 2012. Bioconversion of lignin model compounds with oleaginous Rhodococci. Appl. Microbiol. Biotechnol. 93(2), 891-900.

[45] Lauri, P., Havlík, P., Kindermann, G., Forsell, N., Böttcher, H. Obersteiner, M., 2014. Woody biomass energy potential in 2050 . Energy Policy. 66, 19-31.

[46] Laurichesse, L., Avérous, S., 2014. Chemical modification of lignins: towards biobased polymers. Prog. Polym. Sci. 39(7), 1266 1290.

[47] Lebaka, V., 2013. Potential bioresources as future sources of biofuels production: An Overview, in: Gupta, V., Tuohy, M.G. (Eds.), Biofuel Technol. Springer, Berlin, pp. 223-258.

[48] Leung, D.Y.C., Wu, X., Leung, M.K.H., 2010. A review on biodiesel production using catalyzed transesterification. Appl. Energy. 87(4),1083-1095.

[49] López Barreiro, D., Prins, W., Ronsse, F., Brilman, W., 2013. Hydrothermal liquefaction (HTL) of microalgae for biofue production: state of the art review and future prospects. Biomass Bioenergy. 53, 113-127.

[50] Madeira Jr, J.V., Contesini, F.J., Calzado, F., Rubio, M.V., Zubieta, P., Lopes, D.B., de Melo, R.R., 2017. Agro-industrial residues and microbial enzymes: an overview on the eco-friendly bioconversion into high value-added products, in: Brahmachari, G., Demian, A.L., Adrio, J. (Eds.), Biotechnology of microbial enzymes- Production, biocatalysis and industrial applications. Academic Press, pp. 475 $-511$.

[51] Mahalaxmi, S., Williford, C., 2014. Biochemical conversion of biomass to fuels, in: Chen, W., Suzuki, T., Lackner, M. (Eds.), Handbook of climate change mitigation and adaptation. Springer, New York, pp. 1-28

[52] Mariod, A.A., 2016. Extraction, Purification, and Modification of Natural Polymers, in: Olatunji, O. (Ed.), Natural Polymers. Springer, Cham, pp. 63-91.

[53] McKendry, P., 2002. Energy production from biomass (part 2): conversion technologies. Bioresour. Technol. 83(1), 47-54.

[54] McKendry, P., 2002. Energy production from biomass (part 1): overview of biomass. Bioresour. Technol. 83(1), 37-46.

[55] Mesa, L., González, E., Ruiz, E., Romero, I., Cara, C., Felissia, F., Castro, E., 2010. Preliminary evaluation of organosolv pretreatment of sugar cane bagasse for glucose production: application of $2^{3}$ experimental design. Appl. Energy. 87(1), 109-114. 
[56] Molino, A., Chianese, S., Musmarra, D., 2016. Biomass gasification technology: the state of the art overview. J. Energy Chem. 25(1), 1025 .

[57] Mosier, N., Wyman, C., Dale, B., Elander, R., Lee, Y.Y., Holtzapple, M., Ladisch, M., 2005. Features of promising technologies for pretreatment of lignocellulosic biomass. Bioresour. Technol. 96(6), 673-686.

[58] Nussbaumer, T., 2003. Combustion and co-combustion of biomass: fundamentals, technologies, and primary measure for emission reduction. Energy Fuels. 17(6), 1510-1521.

[59] Pandey, M.P., Kim, C.S., 2011. Lignin depolymerization and conversion: a review of thermochemical methods. Chem. Eng. Technol. 34, 29-41.

[60] Portha, J.F., Parkhomenko, K., Kobl, K., Roger, A.C., Arab, S., Commenge, J.M., Falk, L., 2017. Kinetics of Methanol Synthesis from Carbon Dioxide Hydrogenation over Copper-Zinc Oxide Catalysts, Ind. Eng. Chem. Res. 56(45), 13133-13145.

[61] Rana, R., Nanda, S., Meda, V., Dalai, A.K., Kozinski, J.A., 2018. A review of lignin chemistry and its biorefining conversion technologies. J. Biochem. Eng. Bioprocess. Technol. 1(2).

[62] Rahimpour, M.R., Arab Aboosadi, Z., Jahanmiri, A.H., 2012. Synthesis gas production in a novel hydrogen and oxygen perm-selective membranes tri-reformer for methanol production. J. Nat. Gas Sci. Eng. 9, 149-159

[63] Roos, C.J., 2010. Clean Heat and Power Using Biomass Gasification for Industrial and Agricultural Projects, U.S. Department of Energy.

[64] Rowbotham, J., Dyer, P., Greenwell, H., Theodorou, M., 2012. Thermochemical processing of macroalgae: a late bloomer in the development of third-generation biofuels?. Biofuel. 3(4), 441-461.

[65] Sanchez, C., 2009. Lignocellulosic residues: biodegradation and bioconversion by fungi. Biotechnol. Adv. 27(2), 185-194.

[66] Schaechter, M., 2009. Encyclopedia of Microbiology, in: Nanninga, N. (Ed.), Cell Structure, Organization, Bacteria and Archaea, third ed. Academic Press, New York, pp. 357-374.

[67] Sharma, V.K., 2015. Technology development and innovation for production of next-ge neration biofuel from lignocellulosic wastes, in: Sharma, A., Kar, S. (Eds.), Energy sustainability through green energy. Green Energy Technology. Springer, New Delhi, pp. 315-350.

[68] Shen, D.K., Xiao, R., Gu, S., Luo, K.H., 2011. The pyrolytic behavior of cellulose in lignocellulosic biomass: a review. RSC Adv. 1(9), 1641 1660 .

[69] Singh, N., Singh, J., Kaur, L., Sodhi, N.S., Singh, B.G., 2003. Morphological, thermal and rheological properties of starches from different botanical sources. Food Chem. 81(2), 219-231.

[70] Smolarski, N., 2012. High-value opportunities for lignin: unlocking its potential. Frost \& Sullivan, Paris.

[71] Strezov, V., 2014. Properties of biomass fuels, in: Strezov, V., Evans, T.J. (Eds.), Biomass processing technologies. CRC Press, Boca Raton, pp. 1-32.

[72] Sun, Y., Cheng, J., 2002. Hydrolysis of lignocellulosic materials for ethanol production: a review. Bioresour. Technol. 83(1), 1-11.

[73] Sun, J., Wang, W., Yue, Q., Ma, C., Zhang, J., Zhao, X., Song, Z., 2016. Review on microwavemetal discharges and their applications in energy and industrial processes. Appl. Energy. 175, 141-157.

[74] Taherzadeh, M.J., Karimi, K., 2008. Pretreatment of lignocellulosic wastes to improve ethanol and biogas production: a review. Int. J. Mol. Sci. 9(9), 1621-1651

[75] Tamaki, Y., Mazza, G., 2010. Measurement of structural carbohydrates, lignins, and micro-components of straw and shives: effects of extractives, particle size and crop species. Ind. Crops Prod. 31(3), 534-541

[76] Teymouri, F., Laureano-Perez, L., Alizadeh, H., Dale, B.E., 2005. Optimization of the ammonia fiber explosion (AFEX) treatment parameters for enzymatic hydrolysis of corn stover. Bioresour. Technol. 96(18), 2014-2018.

[77] Tkemaladze, G.S., Makhashvili, K.A., 2016. Climate changes and photosynthesis. Ann. Agrar. Sci. 14(2), 119-126.

[78] Tursi, A., Beneduci, A., Chidichimo, F., De Vietro, N., Chidichimo, G., 2018. Remediation of hydrocarbons polluted water by hydrophobic functionalized cellulose. Chemosphere. 201, 530-539.
[79] Tursi, A., Chatzisymeon, E., Chidichimo, F., Beneduci, A. Chidichimo, G., 2018. Removal of endocrine disrupting chemicals from water: adsorption of bisphenol-a by biobased hydrophobic functionalized cellulose. Int. J. Environ. Res. Public Health. 15(11), 2419.

[80] Tursi, A., De Vietro, N., Beneduci, A., Milella, A., Chidichimo, F., Fracassi, F., Chidichimo, G., 2019. Low pressure plasma functionalized cellulose fiber for the remediation of petroleum hydrocarbons polluted water. J. Hazard. Mater. 373, 773-782.

[81] Vassilev, S.D., Andersen, L., Vassileva, C., Morgan, T., 2012. An overview of the organic and inorganic phase composition of biomass. Fuel, 94, 1-33.

[82] Vassilev, S.V., Baxter, D., Andersen, L.K., Vassileva, C.G., 2010 An overview of the chemical composition of biomass. Fuel. 89(5), 913-933

[83] Vassilev, S.V., Vassileva C.G., 2016. Composition, properties and challenges of algae biomass for biofuel application: an overview. Fuel. 181, 1-33.

[84] Vorwerg, W., Radosta, S., Leibnitz, E., 2002. Study of a preparative-scale process for the production of amylose. Carbohydr. Polym. 47(2), 181-189.

[85] Wang, H., Tucker, M., Ji, Y., 2013. Recent development in chemical depolymerization of lignin: a review. J. Appl. Chem. Article ID 838645

[86] Waniska, R.D., Rooney, L.W., McDonough, C.M., 2016. Sorghum: Utilization, in: Wrigley, C.W., Corke, H., Seetharaman, K. Faubion, J. (Eds.), Encyclopedia of Food Grains, second ed. Academic Press, San Diego, pp. 116-123.

[87] WBA, 2018. WBA Global bioenergy statistics 2018, Summary Report. World Bioenergy Association, www.worldenergy.org.

[88] Wells, T., Ragauskas, A.J., 2016. On the future of lignin-derived materials, chemicals and energy. Innov. Ener. Res. 5(2), 117

[89] Welker, C.M., Balasubramanian, V.K., Petti, C., Rai, K.M., DeBolt, S., Mendu, V., 2015. Engineering plant biomass lignin content and composition for biofuels and bioproducts. Energies. 8(8), 7654-7676.

[90] Werkelin, J., Skrifvars, B.J., Hupa, M., 2005. Ash-forming elements in four Scandinavian wood species. Part 1: summer harvest. Biomass Bioenergy. 29(6), 451-466.

[91] Winger, M., Christen, M., Van Gunsteren, W.F., 2009. On the Conformational Properties of Amylose and Cellulose Oligomers in Solution. Int. J. Carbohydr. Chem. 2009, Article ID 307695.

[92] Xie, S., Ragauskas, A.J., Yaun, J., 2016. Lignin conversion: opportunities and challenges for the integrated biorefinery. Ind Biotechnol. 12(3), 161-167

[93] Xu, F., Zhong, X.C., Sun, R.C., Jones, G.L.L., 2005. Lignin distribution and ultrastructure of Salix psammophila. Trans Chin. Pul Pap. 20(1), 6-9.

[94] Sreekrishnan, T.R., Kohli, S., Rana, V., 2004. Enhancement of biogas production from solid substrates using different techniquesa review. Bioresour. Technol. 95(1), 1-10.

[95] Yokoyama, S., 2008. The Asian Biomass Handbook. A guide for biomass production \& utilization, The Japan Institute of Energy, Tokio.

[96] Yu, G., Zhang, Y., Schideman, L., Funk, T., Wang, Z., 2011 Distributions of carbon and nitrogen in the products from hydrothermal liquefaction of low-lipid microalgae. Energy Environ. Sci. 4(11), 4587-4595.

[97] Zamani, A., 2015. Introduction to lignocellulose-based products in: Karimi, K. (ed.), Lignocellulose-Based Bioproducts. Springer, Cham, pp. 1-36.

[98] Zhang, J., Weng, X., Han, Y., Li, W., Gan, Z., Gu, J., 2013. Effect of supercritical water on the stability and activity of alkaline carbonate catalysts in coal gasification. J. Energy Chem. 22(3), 459-467.

[99] Zhao, X., Zhang, L., Liu, D., 2012. Biomass recalcitrance. Part I the chemical compositions and physical structures affecting the enzymatic hydrolysis of lignocellulose. Biofuel Bioprod. Biorefin. $6(4), 465-482$ 